\title{
Mercury uptake by vegetation and impacts on global mercury cycling
}

1. Department of Environmental, Earth and Atmospheric Sciences, University of Massachusetts, Lowell, 01854, USA

2. Air Quality Research Division, Environment and Climate Change Canada, Dorval, Quebec, Canada H9P 1 J3.

3. Environmental Geosciences, University of Basel, Basel, 4056, Switzerland

4. These authors contributed equally: Jun Zhou and Daniel Obrist

* Co-corresponding authors: jun_zhou@uml.edu (Jun Zhou), and daniel_obrist@uml.edu (Daniel Obrist) 


\begin{abstract}
In this review, we synthesize the current knowledge on mercury $(\mathrm{Hg})$ content and sources in foliage and vegetated ecosystems and the importance of vegetation to global $\mathrm{Hg}$ cycling. By means of a global database of over 35,000 samples across 416 sites, we discuss global $\mathrm{Hg}$ concentrations in all major tissues, and mechanisms of vegetation $\mathrm{Hg}$ uptake. $\mathrm{Hg}$ in aboveground vegetation largely originates from uptake of atmospheric gaseous elemental $\mathrm{Hg}(\mathrm{Hg}(0))$, whereas $\mathrm{Hg}$ in roots originates from a combination of uptake from soil and foliage-to-root transport. Vegetation $\mathrm{Hg}$ uptake from the atmosphere and transfer to soils is the major $\mathrm{Hg}$ source in all biomes. Using model sensitivity analyses with and without global vegetation present, we show that vegetation $\mathrm{Hg}$ uptake modulates atmospheric $\mathrm{Hg}(0)$ seasonality in the northern hemisphere and interhemispheric gradient. We estimate that vegetation uptake the global $\mathrm{Hg}$ pool in the atmosphere by approximately $660 \mathrm{Mg}$ and reduces the $\mathrm{Hg}$ deposition to global oceans, which in the absence of vegetation might receive an additional $960 \mathrm{Mg} \mathrm{yr}^{-1}$. We discuss future research needs to better constrain vegetation uptake mechanisms and their controlling physiological and environmental variables, improve model processes and address effects of climate and land use changes.
\end{abstract}




\section{Key points}

- Studies suggest that $60 \%$ to $90 \%$ of $\mathrm{Hg}$ in forest ecosystems originates from vegetation uptake of atmospheric gaseous elemental $\mathrm{Hg}(0)$, providing 1,310 to $1,570 \mathrm{Mg} \mathrm{yr}^{-1}$ of terrestrial $\mathrm{Hg}$ deposition.

- Lichen and mosses show higher $\mathrm{Hg}$ concentrations than vascular plants. $\mathrm{Hg}$ in aboveground biomass is largely from atmospheric uptake while root $\mathrm{Hg}$ is from combined soil and atmospheric uptake.

- Vegetation uptake of atmospheric $\mathrm{Hg}(0)$ lowers the global atmospheric $\mathrm{Hg}$ burden by $660 \mathrm{Mg}$ and reduces deposition to global oceans, which without vegetation would receive an additional $\mathrm{Hg}$ deposition of $960 \mathrm{Mg} \mathrm{yr}^{-1}$.

- The seasonality of atmospheric $\operatorname{Hg}(0)$ concentrations in the Northern Hemisphere is controlled by vegetation uptake. Simulations without vegetation show weak seasonal cycles and cannot reproduce observations.

- Large knowledge gaps exist in understanding physiological and environmental controls of vegetation Hg uptake and transport within plants, limiting our mechanistic and molecular-level understanding of vegetation $\mathrm{Hg}$ uptake.

- Improved model parametrizations and harmonized observational data of vegetation $\mathrm{Hg}$ uptake along with whole-ecosystem $\operatorname{Hg}(0)$ exchange measurements are needed to improve the assessment of vegetation impacts on global $\mathrm{Hg}$ cycling. 


\section{Introduction}

The Minamata Convention on Mercury to curb anthropogenic mercury ( $\mathrm{Hg}$ ) emissions was signed in 2013 and aims to reduce $\mathrm{Hg}$ risks to humans and the environment worldwide ${ }^{1}$. $\mathrm{Hg}$ is a globally abundant pollutant found in all major Earth's environmental reservoirs (air, soils, waters), with the atmosphere serving as an efficient distribution vector ${ }^{2}$. A recent 2018 Global Mercury Assessment ${ }^{3}$ estimated global anthropogenic $\mathrm{Hg}$ emissions to the atmosphere of approximately 2,220 $\mathrm{Mg}$ (2000-3000) $\mathrm{Mg}$ ) in 2015 . Emissions from biomass burning estimated at approximately $220-612 \mathrm{Mg} \mathrm{yr}^{-1} 4-6$ and terrestrial geogenic (e.g., volcanic emissions and soil degassing) ${ }^{6}$ and legacy emissions from soils and vegetation are approximately 950-1594 $\mathrm{Mg} \mathrm{yr}^{-1}$ 4,6-8 . Legacy emissions are re-volatilization of past atmospheric deposition from anthropogenic and geogenic sources stored in surface reservoirs (e.g., soils and water), and are now considered to dominate global $\mathrm{Hg}$ emissions to the atmosphere, mostly emitted over oceans (2681-3400

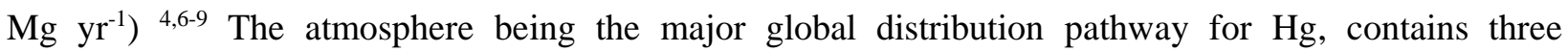
operationally defined forms: gaseous elemental $\mathrm{Hg}(\mathrm{Hg}(0),>95 \%$ of total $\mathrm{Hg})$; and two oxidized $\mathrm{Hg}$ forms ( $\mathrm{Hg}(\mathrm{II}))$ : reactive gaseous $\mathrm{Hg}(\mathrm{RGM})$; and particulate-bound $\mathrm{Hg}(\mathrm{PBM}) . \mathrm{Hg}$ emitted to the atmosphere is transported around the globe where it ultimately deposits and represents the main source to remote aquatic and terrestrial ecosystems ${ }^{2,10,11}$. In these ecosystems, $\mathrm{Hg}$ can be methylated and biomagnified through food webs posing direct risks to human and ecosystem health ${ }^{10,11}$.

Over two decades of research has shown that the dominant source of $\mathrm{Hg}$ in ecosystems is related to vegetation assimilation of atmopsheric $\mathrm{Hg}$ and subsequent transfer to soils and watersheds when vegetation tissues are washed off (termed "throughfall"); vegetation shed leaves (termed "litterfall") 12,13; or when vegetation senesces (i.e., turnover of biomass). Plant roots take up additional $\mathrm{Hg}$ from soils which impacts soil $\mathrm{Hg}$ availability and stabilizes $\mathrm{Hg}$ below ground (termed "phytostabilization") ${ }^{14}{ }^{15,16}$. Recognition of the critical importance of vegetation for terrestrial Hg cycling goes back to the 1990s when studies showed litterfall and throughfall $\mathrm{Hg}$ deposition in forests to exceed direct open-field wet deposition (i.e., by rain and snow) several-fold ${ }^{12,13,17-19}$. Vegetation ultimately plays a critical role in the cycling of $\mathrm{Hg}$ in all major Earth System compartments: field deposition studies show that plant-derived deposition dominates as a source in ecoystems with high plant net primary productivity ${ }^{20}$; atmospheric observations show that vegetation uptake of atmospheric $\operatorname{Hg}(0)$ modulates both its seasonality and its concentrations in the boundary layer ${ }^{21,22}$; soil and sediment studies show that vegetation shapes $\mathrm{Hg}$ loads across landscapes, with densely vegetated ecosystems and productive watersheds exhibiting highest $\mathrm{Hg}$ loads ${ }^{23-28}$; and $\mathrm{Hg}$ assimilated by vegetation is subsequently exported from watersheds via streams ${ }^{29-31} 32,33$ where it can dominate as a source of $\mathrm{Hg}$ in rivers and ocean sediments ${ }^{34,35}$ and is found to bioaccumulate in fish ${ }^{36-38}$.

Here, we review the current knowledge of $\mathrm{Hg}$ uptake by vegetation and its impact on global $\mathrm{Hg}$ cycling. We compile published $\mathrm{Hg}$ concentration data in vegetation tissue from 440 sites in a global database and 
analyze $\mathrm{Hg}$ distribution patterns across ecosystem types, plant functional groups and plant tissues. We discuss pathways of $\mathrm{Hg}$ uptake, translocation within vegetetation and the state of knowledge on $\mathrm{Hg}$ stable isotopes and foliage-atmosphere exchange of $\mathrm{Hg}$ and its representation in global models. Finally, we assess the importance of $\mathrm{Hg}$ uptake by vegetation on $\mathrm{Hg}$ cycling using the global $\mathrm{Hg}$ model GEM-MACH-Hg ${ }^{39-}$ ${ }^{42}$ by conducting simulation sensitivity analyses with and without the presence of vegetation.

\section{Global database and $\mathrm{Hg}$ in vegetation}

We built a comprehensive database collecting peer-reviewed published data on $\mathrm{Hg}$ concentrations measured in vegetation tissues globally. Data stretch from 1976 to 2020 and include 440 different sites, derive from 230 scientific studies and consist of 2,490 reported data representing over 35,000 individual plant tissue measurements (Supplemental information). Hg concentrations are separated into different tissue groups (such as leaves, needles, roots, woody tissues including bole wood, bark, and branches), plant functional types (including lichens, mosses, and vascular plants such as grassland plants, shrubs and trees), species, and geographic areas. Currently available vegetation data are unevenly distributed across the world (e.g., Figure 1a for foliage and litterfall samples) with most data originating from Europe (46.6\%), followed by North America (23.0\%), Asia (17.2\%) and South America (13.1\%). Data are largely lacking from Africa, southern and northern Asia, Australia, Eastern Europe and many Polar Regions. Similar patterns of data coverage are also observed in other tissues (Figure S1). Most vegetation data stem from deciduous trees (77.9\%) and coniferous trees $(9.1 \%)$, while other vegetation types show much lower sample numbers, including evergreen broadleaved trees (4.8\%), grasslands (4.3\%), and wetlands (3.9\%) (Figure 1b). Foliar data, which include leaves, needles, and litterfall (i.e., recently senesced and fallen foliage) represent about $78 \%$ of all available data (Figure 1c). Much fewer data are available from woody tissues, branches, bark and grassland plants which combined account for less than $9.8 \%$ of the data (Figure 1c).

Spatially, foliage and litterfall $\mathrm{Hg}$ concentrations were highest in South America, followed by Europe and Asia, and lowest in North America, with similar spatial patterns observed for other tissues (Figure 1a, S2b and S2c). However, because of large differences in investigated forest types, non-random sampling procedures and some studies including regional (natural or anthropogenic) $\mathrm{Hg}$ contamination hotspots (Box 1), we consider spatial comparisons likely to be biased and refrain from using this global database for detailed analyses of global spatial distribution patterns. Across unpolluted areas, median $\mathrm{Hg}$ concentrations derived from our database across functional groups and vegetation tissues significantly varied in the following order (Figure 1c, median and interquartile ranges [IQR]): lichen (78 $\left.\mu \mathrm{g} \mathrm{kg}^{-1},\left[10-180 \mu \mathrm{g} \mathrm{kg}^{-1}\right]\right)>$ moss $\left(51 \mu \mathrm{g} \mathrm{kg}^{-1}\left[2-165 \mu \mathrm{g} \mathrm{kg}^{-1}\right]\right)>$ litterfall $\left(43 \mu \mathrm{g} \mathrm{kg}^{-1}\left[4-83 \mu \mathrm{g} \mathrm{kg}^{-1}\right]\right)>$ foliage $\left(20 \mu \mathrm{g} \mathrm{kg}^{-1}[2-62 \mu \mathrm{g} \mathrm{kg}\right.$ $\left.\left.{ }^{1}\right]\right)>\operatorname{bark}\left(11 \mu \mathrm{g} \mathrm{kg}^{-1}\left[1-36 \mu \mathrm{g} \mathrm{kg}^{-1}\right]\right)>\operatorname{branch}\left(12 \mu \mathrm{g} \mathrm{kg}^{-1}\left[0.2-37 \mu \mathrm{g} \mathrm{kg}^{-1}\right]\right)>\operatorname{root}\left(7 \mu \mathrm{g} \mathrm{kg}^{-1}\left[2-70 \mu \mathrm{g} \mathrm{kg}^{-}\right.\right.$ 
$\left.{ }^{1}\right]>\operatorname{grass}\left(5 \mu \mathrm{g} \mathrm{kg}^{-1}\left[1-31 \mu \mathrm{g} \mathrm{kg}^{-1}\right]\right)>\operatorname{wood}\left(2 \mu \mathrm{g} \mathrm{kg}^{-1}\left[0.1-6.8 \mu \mathrm{g} \mathrm{kg} \mathrm{kg}^{-1}\right]\right)$. A similar order of $\mathrm{Hg}$ concentrations was observed for vegetation grown in polluted areas (Figure S2a and Box 1). Below, we discuss detailed pathways and mechanism of $\mathrm{Hg}$ uptake and transport behavior within vegetation that explain these observed concentration patterns.

\subsection{Mercury in vascular plants and mechanism of $\mathrm{Hg}$ uptake}

Pathways of $\mathrm{Hg}$ uptake in vascular plants include stomatal and cuticular uptake in foliage ${ }^{43-45}$ (Figure 2), surface adsorption of atmospheric $\mathrm{Hg}$ to foliage ${ }^{46}$ and bark ${ }^{43,47}$, and soil uptake of $\mathrm{Hg}$ through roots. 45,48-51.

There is strong evidence that in aboveground tissues most $\mathrm{Hg}$ originates from assimilation of atmospheric uptake (Figure 2) ${ }^{52}$. Many lines of evidence, including from flux measurements and stable $\mathrm{Hg}$ isotope analyses (Section 4), show that approximately $90 \%$ of $\mathrm{Hg}$ in leaves and needles is derived from atmospheric uptake of gaseous $\mathrm{Hg}(0)$ and that translocation of $\mathrm{Hg}$ from soils to aboveground tissues is limited ${ }^{53-64}$. One study estimated that $11 \%$ of $\mathrm{Hg}$ in a canopy originated from soils via xylem transport ${ }^{65}$, and another study showed less than $5 \%$ of soil solution root $\mathrm{Hg}$ uptake was translocated to shoots ${ }^{45,59,66}$. Most leaf $\mathrm{Hg}$ (90-96\%) is integrated into internal tissues ${ }^{51}$ and a minor part adsorbed to outer leaf surfaces ${ }^{64}$. Inside leaves, $\mathrm{Hg}$ is shown to be incorporated in epidermal and stomatal cell walls as well in parenchyma cell nuclei ${ }^{67}$. This $\mathrm{Hg}$ integrated inside leaves consists of divalent $\mathrm{Hg}$ (II), so there must be an oxidation step after leaf uptake of $\mathrm{Hg}(0)$, although it is currently unknown where and when the oxidation step occurs. Studies propose both stomatal and non-stomatal uptake pathways in leaves, although several studies point towards a dominance of stomatal uptake ${ }^{51,52,56,64,68}$. Evidence of stomatal uptake of gaseous $\mathrm{Hg}(0)$ is based on isotopically labeled $\mathrm{Hg}(0)$ exposures ${ }^{64,67,69}$, natural abundant $\mathrm{Hg}$ stable isotopes ${ }^{60,61}$, sequential leaf extractions ${ }^{51,70}$ and foliage-atmosphere exchange studies ${ }^{46,71}$. Yet, observed $\mathrm{Hg}(0)$ uptake at night also suggests presence of non-stomatal, cuticular $\operatorname{Hg}(0)$ uptake ${ }^{72-74} \cdot \operatorname{Hg}(0)$ uptake is likely controlled by enzymatic processes ( such as catalase activity), which also has been linked to $\mathrm{Hg}$ oxidation in leaves ${ }^{70}$. A recent study identified sulfur nanoparticulate $(\beta-\mathrm{HgS})$ and dithiolate complexes $\left(\mathrm{Hg}(\mathrm{SR})_{2}\right)$ in leaves exposed to high atmospheric $\mathrm{Hg}$ concentrations ${ }^{75}$. Consistent with this, $\mathrm{Hg}$-binding thiol ligands, interpreted as cysteine residues, were identified in ex situ experiments with added $\mathrm{Hg}{ }^{76,77}$.

It is well known, and supported by our database analysis (Figure 1c), that $\mathrm{Hg}$ concentrations in vascular plants are highest in leaves and needles. Because $\mathrm{Hg}$ is taken up from the atmosphere, $\mathrm{Hg}$ concentrations in leaves and needles are highly sensitive to variations in atmospheric $\mathrm{Hg}$ concentrations. Growth chamber and laboratory studies have shown that atmospheric $\mathrm{Hg}(0)$ exposures linearly and positively correlate with $\mathrm{Hg}$ concentrations in shoots, leaves and needles 14,52,54-56,78,79. Field observations also show significant positive correlations between $\mathrm{Hg}(0)$ concentrations in the atmosphere and foliage ${ }^{75,80}$. Using our global 
database, we observed a significant positive linear correlation between leaf and needle $\mathrm{Hg}$ concentrations and atmospheric $\mathrm{Hg}$ concentrations across unpolluted sites $\left(\mathrm{n}=34, \mathrm{r}^{2}=0.32, p<0.01\right)$, a correlation that became even stronger $\left(\mathrm{n}=77, \mathrm{r}^{2}=0.66, p<0.01\right)$ when polluted sites were included.

Many other factors have also been associated with variability in $\mathrm{Hg}$ accumulation in foliage, including underlying geology ${ }^{81}$, solar radiation (in particular UV) ${ }^{82}$, temperature ${ }^{83}$, atmospheric turbulence ${ }^{84}$, leaf age ${ }^{60,85}$, specific leaf area (SLA) ${ }^{51,56}$, number of stomata ${ }^{51}$ and leaf physiological parameters such as stomatal conductance ${ }^{46,71}$, rate of net photosynthesis ${ }^{86}$, waxy cuticles ${ }^{87}$, catalase activity ${ }^{88}$ and ascorbic acid ${ }^{89}$. Many of these processes may be linked to stomatal control of $\mathrm{Hg}$ uptake (such as stomatal conductance, number of stomata, catalase activity) while others may be linked to non-stomatal uptake pathways (such as waxy cuticles and specific leaf area). $\mathrm{Hg}$ concentrations in foliage have been consistently shown to increase with leaf age, both over a growing season ${ }^{51,90}$ and over multiple years in coniferous needles ${ }^{91-93}$. Many studies report higher concentrations in evergreen coniferous tissues than in broadleaf trees due to their multi-year lifetime ${ }^{50,94,95}$. When comparing foliage of the same age, however, coniferous needles have been shown to exhibit lower $\mathrm{Hg}$ concentrations than broadleaf or deciduous trees, which is attributed to a lower metabolic activity of needles ${ }^{90}$ and consistent with reduced deposition in needles using dynamic flux bag measurements $56,58,60,83,85,96$. Although in our database we cannot account for leaf age, we indeed find significantly higher $\mathrm{Hg}$ concentrations in deciduous leaves compared to coniferous needles.

The outermost bark, characterized by a high porosity and relative chemical inertness, lacks metabolic processes and hence likely absorbs airborne $\mathrm{Hg}$ via non-physiological adsorption processes ${ }^{43,47}$. Across the bark, $\mathrm{Hg}$ concentrations markedly decrease from outermost to the innermost layers (including the phloem) ${ }^{97}$ indicating little transport through the bark. Molecular mechanisms involved in $\mathrm{Hg}$ transport within plant are unknown. Potential pathways for $\mathrm{Hg}$ in bole wood include root uptake and translocation through the xylem, foliage uptake and translocation by phloem transport, and transfer from the bark (Figure 2). However, $\mathrm{Hg}$ uptake to bole wood, which is the tissue showing by far lowest $\mathrm{Hg}$ concentrations (Figure 1c and S2a), is considered dominated by translocation of foliage $\mathrm{Hg}$ to tree rings through phloem transport, while transport seems negligible through translocation from roots and bark ${ }^{43-45}$. Recently, a number of studies have tested the use of tree ring $\mathrm{Hg}$ to track historic, local, regional, and global $\mathrm{Hg}$ exposures with promising results $43,44,97-104,105$.

Below ground, it is known that plant roots and plant-produced excretions (chelators) can induce $\mathrm{pH}$ variations and redox reactions in soils, which subsequently can lead to cation exchange of divalent $\mathrm{Hg}$ and solubilization of $\mathrm{Hg}$ from nearly insoluble soil $\mathrm{Hg}$ precipitates ${ }^{106,107}$. As a nonessential element, $\mathrm{Hg}$ likely penetrates into root cells as a hitchhiker using transporters for other elements ${ }^{108,109}$. Absorbed $\mathrm{Hg}$ is largely restricted to the cell walls of the outer layers of the root cortical cylinder and to the central cylinder and parenchyma cell nuclei ${ }^{67}$. The movement of $\mathrm{Hg}$ from the root inwards into the xylem can be diminished 
by $\mathrm{Hg}$ accumulation in root cells and transport of $\mathrm{Hg}$-phytochelatin complexes into vacuoles can restrict phloem mobility ${ }^{109,110}$. Low $\mathrm{Hg}$ translocation from soils to aboveground tissues (see below) has been attributed to effective $\mathrm{Hg}$ retention in roots ${ }^{111}$. However, no specific transport molecules involved in $\mathrm{Hg}$ uptake by roots and translocation in roots are known. Root $\mathrm{Hg}$ concentrations have been shown to linearly correlate with soil $\mathrm{Hg}$ concentrations ${ }^{14,78,112}$ and show low sensitivity to air $\mathrm{Hg}$ concentrations ${ }^{14}$, leading to the notion that $\mathrm{Hg}$ in roots is derived primarily from soil uptake. However, exceptions to this notion have been reported in quaking aspen ${ }^{79}$ and wheat ${ }^{14,56}$ under high atmospheric $\mathrm{Hg}$ exposures. Recent stable $\mathrm{Hg}$ isotope studies have shown contrasting results on $\mathrm{Hg}$ origins in roots. While one study on rice plants grown in contaminated soils showed root $\mathrm{Hg}$ with the same isotopic signature as the surrounding soil ${ }^{113}$, a recent forest study suggested substantial foliage-to-root $\mathrm{Hg}$ transport whereby atmospheric $\mathrm{Hg}(0)$ uptake via foliage accounted for $44-83 \%$ of $\mathrm{Hg}$ in tree roots ${ }^{114}$. In the latter study, large roots showed higher proportions of atmospheric $\mathrm{Hg}(0)$ and lower soil $\mathrm{Hg}$ uptake compared to small roots ${ }^{114}$, possibly related to lower surface areas and reduced absorptive potential of large roots ${ }^{111,115}$. The notion that root $\mathrm{Hg}$ may derive in part or wholly from atmospheric uptake merits further detailed investigations as it would substantially increase estimates of plant $\mathrm{Hg}$ uptake from the atmosphere due to high turnover rates of roots, which may equal that of leaf litterfall ${ }^{111}$.

\subsection{Mercury in non-vascular vegetation}

Lichens and mosses generally show much higher $\mathrm{Hg}$ concentrations compared to vascular plants (Figure 1c and S2a). Lichens and mosses are cryptogamic organisms without root systems and without thick waxy cuticles, have high specific surface areas and slow growth, and are dependent on atmospheric deposition for water and nutrient supply. Generally, lichens show higher $\mathrm{Hg}$ concentrations than mosses in our dataset (Figure S2c). Reason for these patterns include that mosses and lichens have different morphophysiological properties and interception capabilities for airborne particles ${ }^{116}$, and that lichens often accumulate higher contents of atmosphile elements (derived from atmospheric sources), while mosses have shown higher contents of lithophile elements such as dust ${ }^{117-119}$. A lack of thick waxy cuticles in lichens and mosses allows cations to diffuse readily through cell walls ${ }^{120}$. Metals accumulate in mosses and lichens through intracellular and extracellular processes. In the extracellular process, metals are intercepted and ad/absorbed by exchange sites outside of cell walls and plasma membrane surface. In the intracellular process, $\mathrm{Hg}$ is subsequently trapped as particles on the cell surface layer or translocated inside the cell ${ }^{121-}$ 124. In addition to surface deposition of RGM and PBM, $\mathrm{Hg}(0)$ assimilation may contribute to trapping and sequestering of $\mathrm{Hg}$ in moss and lichen tissue, although the specific methods of uptake, binding, and accumulation from the atmosphere are unknown. Although $\operatorname{Hg}(0)$ shows low solubility in water and is easily re-emitted to the atmosphere, it has been shown that both lichens and mosses can rapidly ad/absorb 
$\mathrm{Hg}(0)$ from the atmosphere with increased uptake when exposure is high ${ }^{125}$. Once taken up, laboratory experiments indicate that $\mathrm{Hg}(0)$ is oxidized to $\mathrm{Hg}(\mathrm{II})$ and subsequently immobilized in moss and lichens for 4-5 weeks ${ }^{52,116,126}$. Stable isotopes have been used to identify $\mathrm{Hg}$ source in mosses ${ }^{61,124,127,128}$ and shown atmospheric $\operatorname{Hg}(0)$ to account for $76 \%$ and $86 \%$ in ground and tree mosses, with the remaining $24 \%$ and $14 \%$ originating from $\mathrm{Hg}(\mathrm{II})$ contribution ${ }^{114}$.

$\mathrm{Hg}$ bioaccumulation in mosses and lichens is controlled by numerous biotic and abiotic factors, including: (1) species, whereby different moss and lichen species show large differences in $\mathrm{Hg}$ concentrations under the same exposures ${ }^{125,129,130,131}$; (2) substrate and local soil, ${ }^{122,132,133}$; (3) growth rate and surface area, ${ }^{116,134,135}$, (4) exposure to pollution source ${ }^{52}$; (5) temporal variation ${ }^{135}$; and (6) chemical composition of wet and dry deposition ${ }^{136,137}$. Furthermore, $\mathrm{Hg}$ concentrations in mosses and lichens can maintain a state of dynamic equilibrium with atmospheric $\mathrm{Hg}$ concentrations ${ }^{138,139}$. Although passive biomonitoring would be cost-effective and benefit from abundant distribution, structural simplicity, rapid growth rate and ease of sampling ${ }^{120,124,140}$, the potential use of lichens and mosses as passive biomonitors for atmospheric $\mathrm{Hg}$ has shown limited success, Nickel et al. found weak correlations between atmospheric $\mathrm{Hg}$ deposition and $\mathrm{Hg}$ accumulation in moss and soils across large south-to-north gradients in Norway ${ }^{141}$. Harmens et al. previously showed lack of correlations between modelled atmospheric $\mathrm{Hg}$ deposition and moss concentrations across a large network of sites in Europe and report that moss collected in Norway showed no distinct north-to-south patterns in spite of expected gradients in atmospheric Hg pollution ${ }^{142}$. Therefore, and consistent with previous reviews ${ }^{116,120}$, we conclude that $\mathrm{Hg}$ concentrations in lichens and mosses are impacted by many environmental variables, which complicates its use as a biomonitor for atmospheric $\mathrm{Hg}$ concentrations and deposition. Finally, where lichens and mosses represent a significant component of plant communities, such as in the Arctic tundra, their high tissue concentrations are responsible for high atmospheric deposition loads via uptake of atmospheric $\mathrm{Hg}{ }^{61}$. In these ecosystems, cryptogams containing high in levels of $\mathrm{Hg}$ are important forage substrates for caribou resulting in potential exposure to $\mathrm{Hg}^{143}$.

\section{Vegetation-atmosphere exchange}

Direct measurements of foliage-atmosphere $\mathrm{Hg}$ exchange fluxes have been used to assess sinks (i.e., uptake) and sources (i.e., emissions) of atmospheric $\mathrm{Hg}$ in vegetation ${ }^{144}$ and to study uptake mechanisms (e.g., stomatal versus non-stomatal pathways). There are three suggested pathways of foliage-atmosphere $\mathrm{Hg}$ exchanges: (1) $\mathrm{Hg}(0)$ can exchange bi-directionally at the interface of foliage and the atmosphere 46,56,60,83-85,96,145-147; (2) foliage can assimilate divalent $\mathrm{Hg}$ (II) wet and particle deposition (PBM and RGM) followed by partial or full re-emissions to the atmosphere as $\mathrm{Hg}(0)$ after photochemical reduction ${ }^{58,63,147}$; and (3) transpiration transport of $\mathrm{Hg}$ from soils to foliage whereby $\mathrm{Hg}(0)$ is subsequently emitted, either 
directly or after photochemical reduction ${ }^{65,82,89,148,149}$. Several studies, however, have shown that soil $\mathrm{Hg}$ concentrations generally do not influence leaf-atmosphere exchange fluxes $53,56,145,150,151$, in support of limited root-to-atmosphere transport of $\mathrm{Hg}$ (e.g., via transpiration).

Most foliage flux studies show net uptake of $\mathrm{Hg}(0)$, providing evidence of foliar sinks for atmospheric $\operatorname{Hg}(0){ }^{144}$. Measurements using dynamic flux bags on foliage in the field show bidirectional exchange of $\operatorname{Hg}(0)$. For example, foliage served as net sinks in broadleaved and coniferous forests and in a wetland $60,83,96,147$, while other measurements (e.g., in a saltmarsh and a subtropical coniferous forest) showed vegetation as net $\mathrm{Hg}(0)$ sources to the atmosphere ${ }^{85,146}$. Some variability among studies may be explained by differences in solar radiation where radiation favors photochemical re-emissions, which also becomes apparent by observed diurnal flux variability that shows net emissions during peak solar radiation at midday 60,85 . Variability in flux directions over foliage may also be attributable to methodological challenges as these fluxes are small and difficult to measure ${ }^{152}$. Exposures to elevated $\mathrm{Hg}(0)$ concentrations generally increase net deposition to leaves ${ }^{46,56,84}$ and it has been proposed that foliage-atmosphere fluxes are dependent on atmospheric compensation points ${ }^{144,153}$. Most compensation points are reported to be near or lower than ambient atmospheric $\mathrm{Hg}$ concentrations so that under non-contaminated conditions, net $\mathrm{Hg}$ deposition to foliage should dominate ${ }^{83,147}$. Canopies also shield soil surfaces from incident solar radiation, which strongly reduces underlying soil $\mathrm{Hg}(0)$ emission ${ }^{144,154-156}$. A review of available terrestrial surfaceatmosphere $\mathrm{Hg}(0)$ flux studies reveals that based on the current measurements available, global assimilation by vegetation cannot be determined accurately given that global flux uncertainty over canopies ranges from a net deposition of $513 \mathrm{Mg}$ to a net emission of $1,353 \mathrm{Mg} \mathrm{yr}^{-1} 144$.

Studies of land-atmosphere $\mathrm{Hg}$ fluxes at the ecosystem-level allow us to quantifying dry gaseous component of $\mathrm{Hg}$ deposition over land. Whole-ecosystem $\mathrm{Hg}(0)$ exchange flux studies are largely based on micrometeorological tower techniques and commonly report net $\mathrm{Hg}(0)$ deposition during peak vegetation season $^{10,73,74,83,157-162}$, in support of net $\mathrm{Hg}$ assimilation by vegetation. While time-extended measurements are rare, a few annual time series exist and show net annual deposition of gaseous $\mathrm{Hg}(0)$ between 2 to 29 $\mu \mathrm{g} \mathrm{m}^{-2} \mathrm{yr}^{-1}$ over forest, grassland and tundra ecosystems ${ }^{20,158,163,164}$. Studies over wetlands, in contrast, report net $\mathrm{Hg}(0)$ emissions (9.4-18.4 $\left.\mu \mathrm{g} \mathrm{m}^{-2} \mathrm{yr}^{-1}\right)^{72,165}$, as do forests impacted by regional pollution (58 and $\left.2.6 \mu \mathrm{g} \mathrm{m}^{-2} \mathrm{yr}^{-1}\right)^{166}$. The dominance of net $\mathrm{Hg}(0)$ deposition measured during peak vegetation in upland, non-polluted ecosystems also contrasts with studies of agricultural and bare soil surfaces where net $\operatorname{Hg}(0)$ emissions dominated (55.3 $\mathrm{ng} \mathrm{m}^{-2} \mathrm{hr}^{-1}$ over bare soil, corn, and snow-covered fields in Canada ${ }^{167}$, and 5.5$10.8 \mathrm{ng} \mathrm{m}^{-2} \mathrm{hr}^{-1}$ over bare soil, wheat and corn in agricultural fields in China ${ }^{168}$ ). 


\section{Hg stable isotopes in vegetation}

$\mathrm{Hg}$ stable isotopes provide a fingerprint of the sources and transformation processes in environmental samples ${ }^{2,169,170}$. The seven stable isotopes of $\mathrm{Hg}$ undergo mass dependent fractionation (MDF, $\delta^{202} \mathrm{Hg}$ ) and mass independent fractionation of odd-mass (odd-MIF, $\Delta{ }^{199} \mathrm{Hg}$ and $\Delta \Delta^{201} \mathrm{Hg}$ ) and even-mass numbered (even-MIF, $\Delta^{200} \mathrm{Hg}$ and $\Delta^{204} \mathrm{Hg}$ ) isotopes. Even-MIF is thought to be exclusively produced in the upper atmosphere providing a conservative tracer for atmospheric $\mathrm{Hg}$ species deposited to the Earth surface ${ }^{127}$. Atmospheric $\mathrm{Hg}(0)$ and $\mathrm{Hg}(\mathrm{II})$ in rainfall are characterized by distinct isotope even-MIF signatures (Figure 3a). Specifically, $\Delta^{200} \mathrm{Hg}$ of $\mathrm{Hg}(\mathrm{II})$ in rainfall exhibits positive anomalies of $0.2 \%$ ( $(0.13 \%$ to $0.24 \%$, IQR, $\mathrm{n}=115)$ and the corresponding pool of atmospheric $\mathrm{Hg}(0)$ slightly negative $\Delta^{200} \mathrm{Hg}$ values of $-0.05 \%$ ($0.07 \%$ to $-0.03 \%$, IQR, $\mathrm{n}=117)^{10,20,171-178} . \Delta^{200} \mathrm{Hg}$ measured in foliage of $-0.02 \%$ o (-0.05\% to $0.00 \%$, IQR, $\mathrm{n}=120$ ) is similar to the $\Delta^{200} \mathrm{Hg}$ of atmospheric $\mathrm{Hg}(0)^{10,174,178-182}$, and a mass balance calculation based on $\Delta^{200} \mathrm{Hg}$ reveals that $88 \%$ ( $79 \%$ to $100 \%$, IQR) of $\mathrm{Hg}$ in vegetation originates from the uptake of atmospheric $\mathrm{Hg}(0)$. Foliar uptake of $\mathrm{Hg}(0)$ discriminates heavier $\mathrm{Hg}$ isotopes (straight arrow Figure $3 \mathrm{a}$ ), resulting in negative $\delta^{202} \mathrm{Hg}$ values typically observed in foliage ${ }^{10,61,174,178-183} \cdot \delta^{202} \mathrm{Hg}$ in foliage is depleted by $-1 \%$ to $-3 \%$ relative to atmospheric $\operatorname{Hg}(0){ }^{10,61,127,161,174,178}$, depending on plant species ${ }^{61}$ and proximity to anthropogenic $\mathrm{Hg}$ emission sources ${ }^{178}$. Two studies estimated the fractionation factor of foliar uptake based on $\delta^{202} \mathrm{Hg}$ depletion of atmospheric $\mathrm{Hg}^{0}$ and reported factors of $-2.6 \%{ }^{127}$ and $-4.2 \%{ }^{20}$, respectively. As a result of plant uptake of lighter $\mathrm{Hg}(0)$, corresponding enrichments of heavier $\mathrm{Hg}(0)$ isotopes in the residual atmospheric $\mathrm{Hg}(0)$ pool of the boundary layer has been observed above a high-altitude peat bog in Europe ${ }^{127}$, an Arctic tundra ${ }^{20}$ and deciduous and evergreen forests in South-East Asia ${ }^{74}$ as indicated by higher $\delta^{202} \mathrm{Hg}$ values (empty circles in Figure 3a). Vegetation activity, with foliar uptake resulting in higher residual $\delta^{202} \mathrm{Hg}$ values, along with anthropogenic emission have been identified as two main drivers for spatial and temporal variation of atmospheric $\operatorname{Hg}(0)$ isotope compositions in the northern Hemisphere ${ }^{184}$. A global $\mathrm{Hg}$ isotope box model based on $\delta^{202} \mathrm{Hg}$ and $\Delta^{200} \mathrm{Hg}$ constraints ${ }^{185}$ also supports the findings that terrestrial dry $\mathrm{Hg}(0)$ deposition is a critical global flux, supporting a vegetation control on seasonal variation of atmospheric $\mathrm{Hg}(0)$ concentrations ${ }^{22}$.

Re-emissions of $\mathrm{Hg}(0)$ from foliage from an evergreen forest was associated with odd-MIF suggesting that $\mathrm{Hg}$ incorporated in the leaf structure is photo-chemically reduced resulting in a bi-directional flux of $\mathrm{Hg}(0)$ across stomata ${ }^{161}$. Similarly, small depletions in odd-MIF $\Delta{ }^{199} \mathrm{Hg}$ of approximately $-0.1 \%$ measured in surface soils have been attributed to small losses by photochemical reduction in foliage and litterfall 127,174. Overall, odd-MIF values show small but consistent re-emission signatures on foliar $\mathrm{Hg}$ (Figure S3) providing a promising perspective for quantitative assessments of deposition and losses at the ecosystem scale in the future. 
Deposition of atmospheric $\mathrm{Hg}(0)$ by means of litterfall constitutes the major source of $\mathrm{Hg}$ in plants, organic and mineral soils, and watershed runoff (Figure 3b). Average source contributions of atmospheric $\mathrm{Hg}(0)$ deposition to soils was $57 \%$ to $94 \%$ in North America ${ }^{174,182}, 70 \%$ to Arctic tundra soils in Alaska in the USA ${ }^{10}, 79 \%$ to a high-altitude peatland in the Pyrenees in France, $90 \%$ to boreal forest soils in Sweden ${ }^{181}$ and $26 \%$ in surface soils of Tibetan wetlands in China ${ }^{186}$. Global-scale mass balance estimations, based on $\Delta^{200} \mathrm{Hg}$ patterns, reveal contributions of atmospheric $\mathrm{Hg}(0)$ derived $\mathrm{Hg}$ of $62 \%$ (53\% to $89 \%$, IQR) in organic soils $10,174,181-183,187,188$ and $84 \%$ (70\% to 92\%, IQR) in mineral soils (albeit when neglecting geogenic Hg sources) ${ }^{10,174,180-183,187,188}$. Similarly, in runoff of terrestrial ecosystems, $76 \%$ (60\% to $92 \%$, IQR) of $\mathrm{Hg}$ is derived from deposition of atmospheric $\mathrm{Hg}(0){ }^{183,189}$. The major role and isotope fractionation of foliar uptake of atmospheric $\mathrm{Hg}(0)$ results in a characteristic terrestrial fingerprint, which is propagated to and found to be dominant in freshwater and coastal sediments and biota ${ }^{38,127,190-194}$.

\section{Global importance of vegetation $\mathrm{Hg}$ uptake}

Empirical evidence and model results strongly suggest that the dominant pathway of atmospheric $\mathrm{Hg}$ deposition in terrestrial ecosystems is dry $\mathrm{Hg}(0)$ deposition via vegetation uptake and subsequent transfer to soils ${ }^{10,41,182,195-198}$ and atmospheric $\mathrm{Hg}(0)$ taken up by vegetation is the primary driver for $\mathrm{Hg}$ storage in surface soils ${ }^{25,186}$. In turn, plant $\mathrm{Hg}(0)$ uptake controls seasonal variations and global distribution of atmospheric mercury concentrations ${ }^{22}$. Climate-change induced alterations in vegetation and humaninduced land use changes have significant impacts on global $\mathrm{Hg}$ cycling ${ }^{2,186}$. Here, we review studies on the global impacts of vegetation $\mathrm{Hg}$ assimilation on environmental and ecosystem processes based on published empirical studies and modeling results.

\subsection{Empirical studies on global vegetation $\mathrm{Hg}$ uptake}

Global estimates of $\mathrm{Hg}$ uptake by vegetation are available based on field-based litterfall and throughfall measurements. Studies show forests as strong sinks for atmospheric $\operatorname{Hg}(0)^{18,24,25,80,199}$, driven by litterfall which exceeds all other pathways of $\mathrm{Hg}$ inputs. Global $\mathrm{Hg}$ litterfall fluxes are estimated between 1,180 \pm

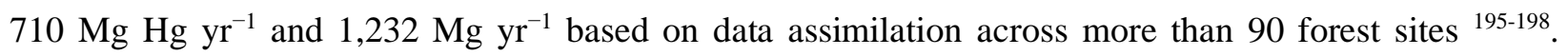
Litterfall deposition has been proposed to decrease along with primary productivity from tropical to temperate to boreal regions with approximately $70 \%$ of global litterfall deposition estimated to occur in tropical and subtropical regions ${ }^{198}$. One study ${ }^{200}$ estimated annual mean $\mathrm{Hg}(0)$ dry deposition in terrestrial ecosystem could be enhanced by up to $20 \%$ in the northern mid-latitudes by 2050 due to increases in plant productivity associated with $\mathrm{CO}_{2}$ fertilization. Litterfall deposition constitutes the dominant deposition to terrestrial environments with vegetation assimilating approximately $1 / 4$ of the total global atmospheric $\mathrm{Hg}$ pool (approximately 4,400-5,300 Mg) each year. Throughfall $\mathrm{Hg}$ deposition may be of similar magnitude 
as litterfall deposition and, although much more uncertain, may globally account for $1,340 \mathrm{Mg}^{\text {year }}{ }^{-1} 80,186$, or $90 \%, 75 \%$ and $143 \%$ of respective litterfall $\mathrm{Hg}$ deposition in China, Europe, and North America, respectively.

We note, however, that the sum of litterfall plus throughfall deposition represents a lower-bound estimate of total vegetation $\mathrm{Hg}$ uptake because it doesn't account for $\mathrm{Hg}$ deposition via woody tissues, nonvascular lichen and mosses, and whole plant senescence (e.g., tree blowdown), nor does it account for direct soil uptake ${ }^{2}$. For example, studies report that $\mathrm{Hg}$ in tree woods is equal to several-fold the $\mathrm{Hg}$ mass contained in canopies ${ }^{201-204}$ and woody tissues (tree turnover) may account for $60 \%$ of litterfall deposition 205 , in spite of slower turnover rates of wood. Analysis along a forest succession suggest that combined woody biomass, moss and throughfall deposition exceed litterfall, thus using litterfall deposition only would strongly underestimate $\mathrm{Hg}$ accumulation in forest soils ${ }^{186}$. If significant amounts of root $\mathrm{Hg}$ is indeed also derived from atmospheric uptake ${ }^{114}$, root turnover will further increase atmospheric dry deposition (section 2.1.).

After plant-bound $\mathrm{Hg}$ is transferred to soils and forests floors, the fate and mobility of $\mathrm{Hg}$ in soils and watersheds depends on litter decomposition and biogeochemical cycling of organic matter ${ }^{94,206-210}$. While a review of the fate and cycling of $\mathrm{Hg}$ in litter and soils is beyond the scope of this review, a comprehensive understanding of the environmental fate and mobility of plant-deposited $\mathrm{Hg}$ is lacking. During litter decomposition, mass and concentrations of $\mathrm{Hg}$ increase due to relatively stronger losses of carbon compared to $\mathrm{Hg}$ and due to continued absorption of $\mathrm{Hg}$ from precipitation and throughfall during initial stages of litter decomposition ${ }^{206,209,211}$. Stable $\mathrm{Hg}$ isotope studies suggest that microbial reduction and photo-reduction also play a role in $\mathrm{Hg}$ losses from litter and soils ${ }^{181,210}$, possibly leading to large re-evasion losses over long time periods. Still, large amounts of plant-derived $\mathrm{Hg}$ are likely retained in soils leading to high pool sizes of $\mathrm{Hg}$ across soils worldwide $2,186,212$.

\subsection{Model approaches of vegetation Hg uptake}

Several studies examined advances and limitations of methods of terrestrial-atmosphere $\mathrm{Hg}$ exchange processes in global models ${ }^{152,196,213,214}$. Dry deposition of $\mathrm{Hg}$ is driven by advection and diffusion in air followed by heterogeneous uptake by surfaces ${ }^{215}$, generally parameterized in models using an inferential approach (i.e., product of ambient $\mathrm{Hg}$ concentration and modeled dry deposition velocity) ${ }^{8,39,216-219}$. Dry deposition velocities over various surface types are estimated through a resistance analogy that includes aerodynamic, soil, stomatal and cuticle resistances ${ }^{220-223}$. Parameters for oxidized $\mathrm{Hg}$ (II) species deposition are selected based on similarity of solubility and reactivity of $\mathrm{Hg}$ with other well-studied atmospheric compounds ${ }^{224}$. A wide range of $\operatorname{Hg}(0)$ dry deposition schemes have been implemented in models; early studies assumed small and constant deposition velocities over vegetated surfaces or neglected $\operatorname{Hg}(0)$ 
deposition all together, and resistance-based $\mathrm{Hg}(0)$ deposition schemes are commonly employed now ${ }^{225}$. Zhang et al. (2009) ${ }^{223}$ reviewed dry deposition velocities of $\mathrm{Hg}$ species and derived dry deposition parameters for $\mathrm{Hg}(0)$ (implemented in the GEM-MACH-Hg model). Models parameterize terrestrial $\mathrm{Hg}(0)$ emissions as a function of environmental conditions (i.e., temperature, solar irradiance, leaf area index) and soil $\mathrm{Hg}$ content, and often include a fraction of recently deposited $\mathrm{Hg}$ to soils, vegetation and snow as prompt re-emissions ${ }^{226-234}$. A few bidirectional air-surface $\mathrm{Hg}$ exchange schemes have been developed and implemented in regional models ${ }^{213,226,235,236}$. One study formulated $\mathrm{Hg}$ exchange fluxes over canopy as concentration gradients across air-foliage/soil by defining dynamic compensation points based on partitioning coefficients ${ }^{235}$. This was subsequently revised ${ }^{236}$ by updating surface resistances ${ }^{222,223,237}$ and implementing photochemical reduction of $\mathrm{Hg}$ in foliage ${ }^{238}$. Wright and Zhang (2015) ${ }^{213}$ reviewed $\mathrm{Hg}(0)$ compensation points over a variety of canopies and environmental conditions in North America (range, 0.5-33 $\mathrm{ng} \mathrm{m}^{-3}$ ) and developed a bidirectional air-surface exchange model based on dry deposition scheme 222,223 and empirical compensation points.

Simulated $\mathrm{Hg}$ exchange fluxes in canopy and underlying soils are highly sensitive to resistance parameters, some of which are poorly constrained ${ }^{64,239}$. Based on direct micrometeorological measurements of $\mathrm{Hg}(0)$ fluxes, a recent study ${ }^{240}$ recommended that current models should increase stomatal resistances to reduce overestimation of stomatal uptake of $\operatorname{Hg}(0)$ (e.g., by a factor of 5-7) and simultaneously increase ground and cuticular uptake to mimic nighttime and wintertime $\mathrm{Hg}(0)$ deposition (by factors of 3-4 and 24, respectively). Current bidirectional $\mathrm{Hg}$ exchange schemes depend on numerous ill-constrained parameters and over-simplified chemistry ${ }^{213,235,236}$ and mechanistic bidirectional air-foliage $\mathrm{Hg}$ partitioning schemes are needed which incorporate biome-specific biomass data, plant physiology, redox chemistry and environmental variables (temperature, light, moisture, atmospheric turbulence) ${ }^{152,214}$.

\subsection{Model understanding of the global $\mathrm{Hg}$ cycle and vegetation $\mathrm{Hg}$ uptake}

We performed two global model simulations using the GEM-MACH-Hg model ${ }^{41,42,225,227,241,242}$ to assess the impacts of vegetation Hg uptake on contemporary atmospheric Hg cycling (year 2015); one with and a second without the presence of vegetation (see details of modeling approach in Text S2 of SI). The simulation without vegetation cover was configured by replacing all biome types to desert, while keeping primary (geogenic and anthropogenic) and secondary (recycling of historic deposition) $\mathrm{Hg}$ emissions unchanged. Our model simulations allowed examination of the significance of vegetation $\mathrm{Hg}$ uptake to the residence time of $\mathrm{Hg}$ in the atmosphere, levels and spatiotemporal distribution of $\mathrm{Hg}$ in air, and $\mathrm{Hg}$ deposition to the Earth's ecosystems. Figure 4 (also Table S1) illustrates the contemporary global Hg cycle and annual $\mathrm{Hg}$ exchange fluxes from the GEM-MACH-Hg simulation with vegetation, along with previous model estimates from the literature. Global oceans are considered a net sink for atmospheric $\mathrm{Hg}$, with annual 
net deposition (deposition minus emission) reported in the literature ranging from 400 to $1,700{\mathrm{Mg} \mathrm{yr}^{-1} 4,6,7}^{4}$ and GEM-MACH-Hg model estimate of $1,300 \mathrm{Mg} \mathrm{yr}^{-1}$. Terrestrial deposition in the GEM-MACH-Hg simulation is estimated at $2,800 \mathrm{Mg} \mathrm{yr}^{-1}$ (literature range of 2,200 to 3,600 $\mathrm{Mg} \mathrm{yr}^{-1}$ ) ${ }^{4,6,7}$. Atmospheric $\mathrm{Hg}$ deposition is divided into wet deposition (via rain and snow) and dry deposition (gravitational settling of particulates and gaseous uptake) ${ }^{223}$. Using the GEM-MACH-Hg model simulation, we estimate global terrestrial wet depositon to be in the range of 730-1,070 $\mathrm{Mg} \mathrm{yr}^{-1}$, which accounts for only $26-38 \%$ of total terrestrial deposition. Dry $\mathrm{Hg}$ deposition in the range of $1,730-2,070 \mathrm{Mg} \mathrm{yr}^{-1}$ is estimated to dominate across terrestrial enviroments, with direct vegetation uptake accounting for the largest portion $(1,310-1,570 \mathrm{Mg}$ $\mathrm{yr}^{-1}$ ) consistent with current litterfall-based estimates ${ }^{198}$. Our model simulations also estimate that gaseous assimilation of $\operatorname{Hg}(0)$ accounts for $90 \%$ of total dry deposition to vegetation, replicating the evidence from experimental data, stable $\mathrm{Hg}$ isotope analyses and field flux studies.

Comparison of GEM-MACH-Hg simulations with and without vegetation show that $\mathrm{Hg}$ uptake by vegetation reduces the residence time of atmospheric $\mathrm{Hg}(0)$ from 10 to 8 months (thus, reduces global atmospheric $\operatorname{Hg}(0)$ concentrations; Figure 5a and 5b), and lessens the global atmospheric $\operatorname{Hg}(0)$ burden from 5,120 to 4,460 Mg. Vegetation $\mathrm{Hg}$ uptake reduces the inter-hemispheric gradient (northern versus southern hemisphere) of $\mathrm{Hg}(0)$ from 1.8:1.1 $\mathrm{ng} \mathrm{m}^{-3}$ to 1.5:1.0 $\mathrm{ng} \mathrm{m}^{-3}$ (Figure 6a). The vegetation $\mathrm{Hg}$ sink notably reduces air concentrations of $\mathrm{Hg}(0)$ over forested regions, e.g. by $25 \%$ over eastern North America and by $35 \%$ over boreal forests in Europe (Figure 5a and 5b). Uptake of $\mathrm{Hg}$ transported out of the source regions by local and regional vegetation lowers the long-range transport and deposition of $\mathrm{Hg}$ in remote regions such as the Arctic and global oceans (Figure 5c and 5d). Simulated (with and without vegetation cover) and measured average seasonal cycles of surface air $\operatorname{Hg}(0)$ concentrations in northern and southern hemispheres are presented in Figures $6 \mathrm{~b}$ and $6 \mathrm{c}$, and at individual observation sites (including different biomes, coastal, urban and polar locations) are shown in Figures S4-S8. Seasonal atmospheric $\operatorname{Hg}(0)$ concentrations are characterized by winter to early spring maxima and late summer to fall minima, especially over vegetated surfaces in the northern hemisphere (Figures $6 \mathrm{~b}$ and S4-S7). In contrast, southern hemispheric locations lack systematic seasonal cycles (Figures $6 \mathrm{c}$ and S8). Our model analyses suggest that northern hemispheric seasonal $\mathrm{Hg}(0)$ cycles over land are controlled by (in order of importance); (i) vegetation uptake (maximum in summer and fall); (ii) terrestrial soil and vegetation emissions (maximum in summer); (iii) cryosphere re-emissions (peak in spring and minimum in fall); and (iv) wildfire emissions (spring to summer). Continued deposition of $\operatorname{Hg}(0)$ to the biosphere into fall results in hemispheric-scale depletion of ambient $\mathrm{Hg}(0)$ concentrations in late summer to fall months. In the absence of $\mathrm{Hg}$ uptake by vegetation, atmospheric $\mathrm{Hg}(0)$ concentrations increase and pronounced seasonal variations are lost (yellow lines, Figure $6 \mathrm{~b}$ and S4-S7). In the southern hemisphere, more variable and unclear seasonal cycles of $\mathrm{Hg}(0)$ are reported (Figures 6c and S8). These model results are consistent with a previous global analysis of 
atmospheric data that concluded that seasonality in $\mathrm{Hg}(0)$ was strongly related to leaf area cover and that summertime minima at remote sites in the Northern Hemisphere were best explained by seasonal vegetation uptake $^{21}$.

Global $\mathrm{Hg}$ deposition is largest in areas of high atmospheric $\mathrm{Hg}$ concentrations associated with anthropogenic emission regions (e.g., South-East Asia) and areas of high biomass production (e.g. Amazon region and Congo basin) (Figure 5c). GEM-MACH-Hg estimates of annual (median) dry deposition $\mathrm{Hg}$ fluxes to major global biomes are as follows (see comparison with litterfall-inferred values in Table S2) ${ }^{198}$. tropical moist broadleaf forests: $27.3 \mu \mathrm{g} \mathrm{m}^{-2} \mathrm{yr}^{-1}$; tropical dry broadleaf forests: $24.6 \mu \mathrm{g} \mathrm{m}^{-2} \mathrm{yr}^{-1}$; temperate broadleaf/mixed forests: $18.3 \mu \mathrm{g} \mathrm{m}^{-2} \mathrm{yr}^{-1}$; tropical grasslands $16.4 \mu \mathrm{g} \mathrm{m}^{-2} \mathrm{yr}^{-1}$, temperate conifers: $14.3 \mu \mathrm{g}$ $\mathrm{m}^{-2} \mathrm{yr}^{-1}$; temperate grasslands: $9.2 \mu \mathrm{g} \mathrm{m}^{-2} \mathrm{yr}^{-1}$; boreal forests: $8.3 \mu \mathrm{g} \mathrm{m}^{-2} \mathrm{yr}^{-1}$ and Arctic tundra: $4.2 \mu \mathrm{g} \mathrm{m}{ }^{-2}$ $\mathrm{yr}^{-1}$. Underestimation of model deposition to vegetation in tropical forests might be linked to the adsorption of wet deposition on foliage ${ }^{58,147}$, as partitioning of $\mathrm{Hg}$ wet deposition between foliage and ground is currently not represented in models.

As summarized above, GEM-MACH-Hg estimates global annual total $\mathrm{Hg}$ deposition of approximately $6,400 \mathrm{Mg}$, with about $44 \%$ deposited to terrestrial ecosystems $\left(\sim 2,800 \mathrm{Mg} \mathrm{y}^{-1}\right)$ of which between $62-74 \%$ occurs as dry deposition, largely in the form of $\mathrm{Hg}(0)(87 \%) \mathrm{Hg}(0)$ accounts for approximately $90 \%$ of foliage $\mathrm{Hg}$ uptake and represents the single largest terrestrial removal pathway of atmospheric $\mathrm{Hg}(1,180-$ $\left.1,410 \mathrm{Mg} \mathrm{yr}^{-1}\right)$. In the absence of vegetation cover, the majority of emitted $\mathrm{Hg}$ would be removed from the atmosphere by wet deposition (over land and oceans), thereby repartitioning the deposition between land (29\%) and ocean $(71 \%)$ and increasing the $\mathrm{Hg}$ deposition to global oceans by approximately $960{\mathrm{Mg} \mathrm{yr}^{-1}}^{-1}$ (Figure 5d). Note that uncertainties in above sensitivity analyses are related to the representation of redox processes and heterogeneous $\mathrm{Hg}$ chemistry in terrestrial components such as vegetation, soils and snow (reflected in the estimated range of fluxes) as well as legacy $\mathrm{Hg}$ cycling in soils (i.e., from past deposition), which was not examined here. The impacts of vegetation on legacy $\mathrm{Hg}$ fluxes are complex and requires further knowledge of terrestrial $\mathrm{Hg}$ accumulation, speciation and lifetime for formulations in threedimensional atmosphere-land-ocean biogeochemical models ${ }^{243,244}$ (see also Text S2 in SI).

\section{Summary and future perspectives}

Vegetation uptake of atmospheric $\mathrm{Hg}$ represents the most important deposition pathway to terrestrial surfaces. Studies based on $\mathrm{Hg}$ stable isotopes, enriched isotope tracer experiments, laboratory and ecosystem-level flux measurements, and model simulations consistently review that approximately $90 \%$ of $\mathrm{Hg}$ in foliage originates from the uptake of atmospheric $\mathrm{Hg}(0)$. At the ecosystem level, 60 to $90 \% \mathrm{of} \mathrm{Hg}$ originates from vegetation uptake of atmospheric $\mathrm{Hg}(0)$. Leaves exhibit the highest $\mathrm{Hg}$ concentrations among plant tissues in vascular plants. $\mathrm{Hg}$ in woody biomass also originates predominantly from leaf uptake 
of atmospheric $\operatorname{Hg}(0)$ which subsequently is translocated within plants, so that woody turnover represents a considerable, yet largely unquantified, source of additional $\mathrm{Hg}$ deposition. Roots have been shown to take up $\mathrm{Hg}$ from surrounding soils, and the transfer of $\mathrm{Hg}$ from roots to aboveground tissues is minor. $\mathrm{Root} \mathrm{Hg}$ dynamics, hence, partly represents internal recycling of $\mathrm{Hg}$ within soils. Recent evidence, however, also indicates foliage-to-root transport, which in effect would further increase plant $\mathrm{Hg}$ uptake from the atmosphere and subsequent deposition. Finally, $\mathrm{Hg}$ concentrations in lichen and mosses exceed concentrations in vascular plants and should be accounted for when quantifying ecosystem $\mathrm{Hg}$ deposition.

The modeling estimate of global $\mathrm{Hg}$ uptake by terrestrial vegetation of 1,310 to $1,570 \mathrm{Mg} \mathrm{yr}^{-1}$ is within the uncertainties of the current best estimates based on litterfall data (approximate mean of $1200 \mathrm{Mg} \mathrm{yr}^{-1}$ ). Global throughfall (estimated at $1,300 \mathrm{Mg} \mathrm{yr}^{-1}$ ) to the terrestrial surfaces also include a proportion of the vegetation $\mathrm{Hg}$ uptake. Sensitivity analyses show that vegetation uptake of $\mathrm{Hg}(0)$ lowers the global atmospheric burden of $\mathrm{Hg}$ from 5,120 to $4,460 \mathrm{Mg}$, in effect reducing long-range $\mathrm{Hg}$ transport and deposition of $\mathrm{Hg}$ to global oceans by $960 \mathrm{Mg} \mathrm{yr}^{-1}$. Vegetation $\mathrm{Hg}$ uptake has a major control on spatial and temporal variability of atmospheric $\mathrm{Hg}(0)$ concentrations globally. Vegetation $\mathrm{Hg}$ uptake leads to late summertime minima in atmospheric $\operatorname{Hg}(0)$ concentrations in remote areas of the northern hemisphere and lowers the interhemispheric $\mathrm{Hg}(0)$ gradient. Ultimately, $\mathrm{Hg}$ taken up by vegetation and deposited to soils is transferred to downstream aquatic freshwater ecosystems and coastal seas, representing a major source of $\mathrm{Hg}$ for aquatic organisms.

A number of research areas merit further focus in order to improve our understanding of the processes controlling $\mathrm{Hg}$ uptake by vegetation and its implications to global $\mathrm{Hg}$ cycling. In particular, assessment of the complex questions on how climate and land use changes will affect global $\mathrm{Hg}$ cycling are currently hampered by a series of shortcomings in process understanding, observational constraints and model representations. Important knowledge gaps exist with respect to the vegetation interfacial $\mathrm{Hg}$ exchange processes; a mechanistic and quantitative knowledge of heterogeneous biochemical processes of plant tissue and soil Hg uptake, considering physiological and environmental drivers, is needed. In order to allow better comparison of data, future studies on $\mathrm{Hg}$ in vegetation should report detailed descriptions of the sampling data such as locations within the canopy, time of sampling, and needle age in coniferous trees, and ideally follow standardized sampling protocols and report environmental exposures (atmosphere and soils). We call for the integration of $\mathrm{Hg}$ data in litterfall and throughfall deposition monitoring networks across all biomes, with a particular focus given to areas of high net primary production where currently observational data are scarce. Litterfall and throughfall measurements are not sufficient to estimate wholeecosystem $\mathrm{Hg}$ deposition as they don't account for the depositon by woody tissues, translocation to roots, uptake by cryptogamic vegetation and direct sorption of $\operatorname{Hg}(0)$ to soils and forest floors. Hence, we recommend measurements of annual time-series of ecosystem-level $\mathrm{Hg}(0)$ deposition across all major 
representative global biomes to constrain their net sinks. Furthermore, significant uncertainties exist in the model parametrizations of surface uptake processes of $\mathrm{Hg}$ species, preventing accurate determination of the relative roles of wet and dry deposition and elemental and oxidized $\mathrm{Hg}$ species in atmosphere-terrestrial $\mathrm{Hg}$ exchange processes. $\mathrm{Hg}$ stable isotope measurements may prove vital to quantify deposition species and process attribution and, thus, improve model parametrizations. Finally, amounts and geospatial distribution of soil $\mathrm{Hg}$ and secondary $\mathrm{Hg}$ emissions (legacy soil and wildfire emissions) are profoundly impacted by foliage $\mathrm{Hg}$ uptake and changes in vegetation cover would alter these. Dynamically coupled $\mathrm{Hg}$ models of atmosphere, terrestrial and ocean environments are needed to simulate the effects of both direct and indirect changes in vegetation; measurement and modeling innovations providing mechanistic knowledge of $\mathrm{Hg}$ processes in terrestrial ecosystems is critical to achieving this goal.

\section{Acknowledgments}

We would like to thank Dr. Xun Wang and Che-Jen Lin for providing us with Hg litterfall deposition fluxes and biome geospatial boundary masks that allowed us to compare model results with litterfall deposition for various biomes of the world. We thank three anonymous reviewers and the journal editor for constructive comments to an earlier version of this manuscript. Funding was provided by the U.S. National Science Foundation (AGS award \# 1848212 and DEB award \# 2027038). M. J .acknowledges funding from the Swiss National Science Foundation grant PZ00P2_174101. We thank James Gray for editorial comments to the manuscript.

\section{Author contributions}

All authors contributed to the writing, editing and overall conceptualization of this review manuscript. J.Z. built the database and conducted analyses of patterns, led the writing of the manuscript and overall design of graphics and tables. D.O. intitated and coordinated the project and co-led manuscript writing and editing. A.D. led the model apporach, analysis, and associated sections. A.R. built the modeling set-up, simulations, anlysis and associated graphics. M.J. led sections on stable $\mathrm{Hg}$ isotope patterns, data collection, and analysis and associated graphics.

\section{Competing interest}

The authors declare no competing interests.

\section{Box 1. The role of vegetation in Hg-enriched areas}


In our database, we also analyze vegetation tissue $\mathrm{Hg}$ concentrations in $\mathrm{Hg}$-enriched areas if studies reported specific point sources or regional pollution sources nearby or if studies were conducted in and near urban and industrial, mining, or smelting sites. In addition to anthropogenic $\mathrm{Hg}$ contamination, natural $\mathrm{Hg}$ enrichments exist along the global mercuriferous belts found along Earth plate margins leading to largescale Hg mineralization zones: Circum-Pacific, Mediterranean, Central Asia and Mid Atlantic Ridges, with many $\mathrm{Hg}$ mines distributed along these zones ${ }^{245}$. When exposed to high soil and atmospheric $\mathrm{Hg}$ levels, plant growth may be decreased due to $\mathrm{Hg}$ toxicity ${ }^{246-249}$. However, most plants grow normally under lightly to moderately polluted areas, but will show substantial $\mathrm{Hg}$ enrichments in their tissues. In comparison with remote, non-enriched sites, median $\mathrm{Hg}$ concentrations of vegetation from $\mathrm{Hg}$-enriched areas in our database show significantly higher $\mathrm{Hg}$ concentrations $(p<0.01)$ by factors of $1.2-5.7$ across all tissues. Specific tissue responses are dependent on the type of exposure, with soil $\mathrm{Hg}$ contamination resulting largely in elevated root $\mathrm{Hg}$ concentrations, while not significantly affecting aboveground tissue concentrations. In turn, atmospheric $\mathrm{Hg}$ contamination significantly elevates $\mathrm{Hg}$ levels in aboveground $\mathrm{Hg}$ concentrations ( $p$ $<0.01$ ), but did not impact belowground tissues.

The potential use of plant $\mathrm{Hg}$ uptake has received interest as an alternative method for traditional physicochemical methods of remediation of $\mathrm{Hg}$-enriched sites, termed phytoremediation. In summary, there are three main approaches of $\mathrm{Hg}$ phytoremediation: phytostabilization, phytovolatilization and phytoextraction. Phytostabilization immobilizes $\mathrm{Hg}$ in soil through biochemical processes, either via $\mathrm{Hg}$ accumulation in roots or chelating $\mathrm{Hg}$ in the root zone. Candidate plants used for phytostabilization have extensive root systems, are tolerant to $\mathrm{Hg}$ toxicity, and are adaptive to site-specific environments ${ }^{246-249}$. Phytovolatilization is unique to $\mathrm{Hg}$ due to its relatively high volatility. Phytovolatilization refers to the uptake of elements by plant roots, translocation through the xylem, and subsequent emission to the atmosphere ${ }^{15}$. There are few studies on phytovolatilization of $\mathrm{Hg}$ via vegetation, however, in part due to its inefficiency $\left(<0.98 \%\right.$ remediation ${ }^{250}$, difficulties in monitoring volatilization fluxes, and possibly due to concern over secondary contamination by emitting $\mathrm{Hg}$ to the atmosphere.

Most studies on phytoremediation have focused on phytoextraction whereby $\mathrm{Hg}$ is removed from soil by harvesting vegetation that has taken up $\mathrm{Hg}$ from soils. Up to now, no plant has been identified as a $\mathrm{Hg}$ hyperaccumulator, which are plants that are capable of growing under high contamination and take up metals via roots and bioconcentrate them in their shoots ${ }^{251}$. Vegetation known to show a potential to bioaccumulate $\mathrm{Hg}$ have shown to remove less than $0.2 \%$ of the $\mathrm{Hg}$ in $\mathrm{Hg}$-enriched soils, even when chemically assisted ${ }^{252-255}$. Hence, in contrast to some other toxic trace metals where phytoextraction is highly efficient (e.g., 32.4-84.5\% removal of soil cadmium by Sedum plumbizincicola ${ }^{256}$ ), phytoextraxtion is considered of low efficiency for $\mathrm{Hg}$. 

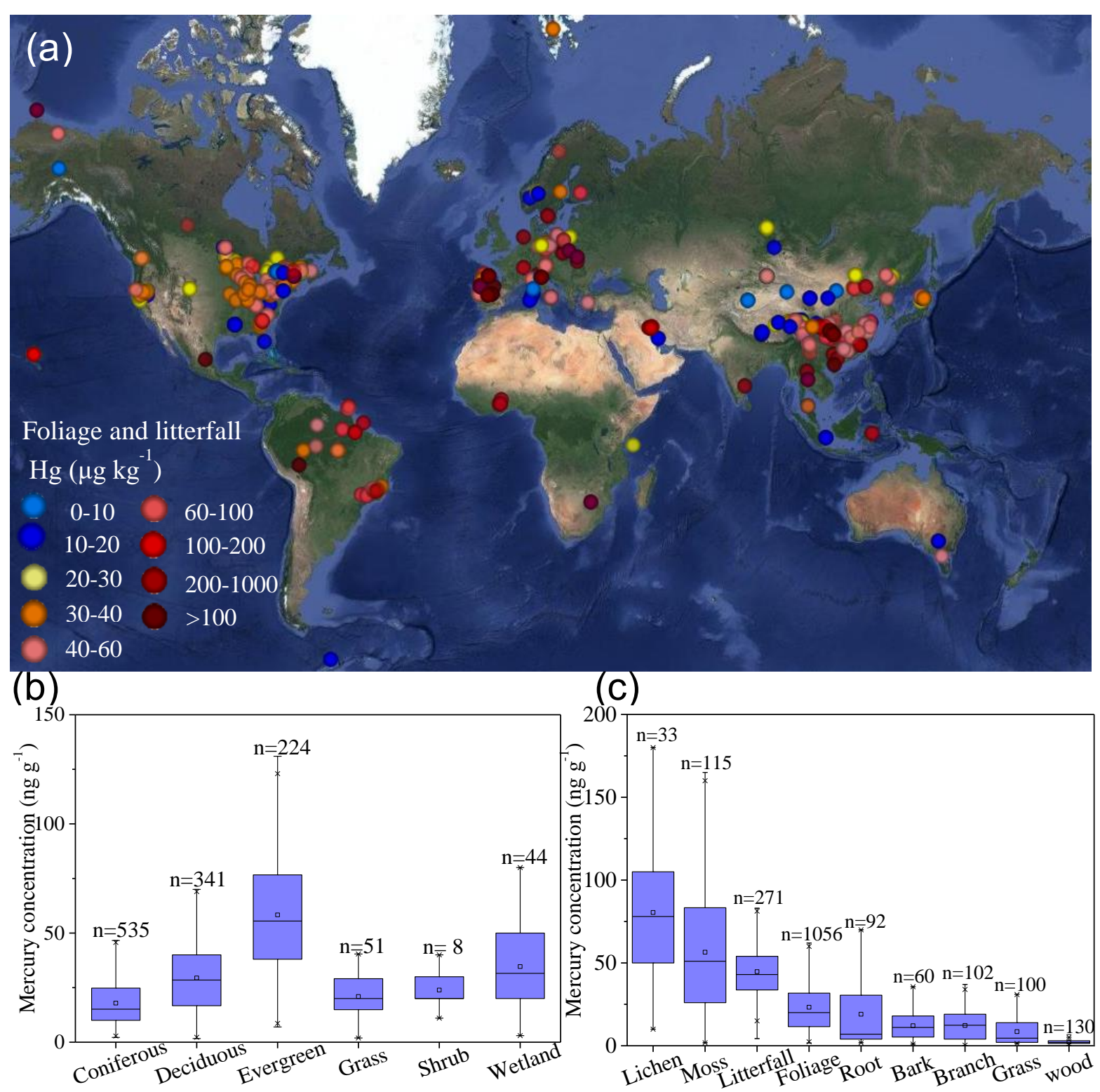

Figure 1. a. Spatial coverage of foliar $\mathrm{Hg}$ samples from our database including both background and $\mathrm{Hg}$ enriched areas, with concentration averaged for sites. b. Box plots of $\mathrm{Hg}$ concentrations of foliage in background sites separated by biomes/plant community types. c. Box plots of $\mathrm{Hg}$ concentrations for various vegetation types and functional groups from background sites. Numbers represent number of data points per group. Corresponding data for Hg-enriched sites are shown in Figure S2a. 


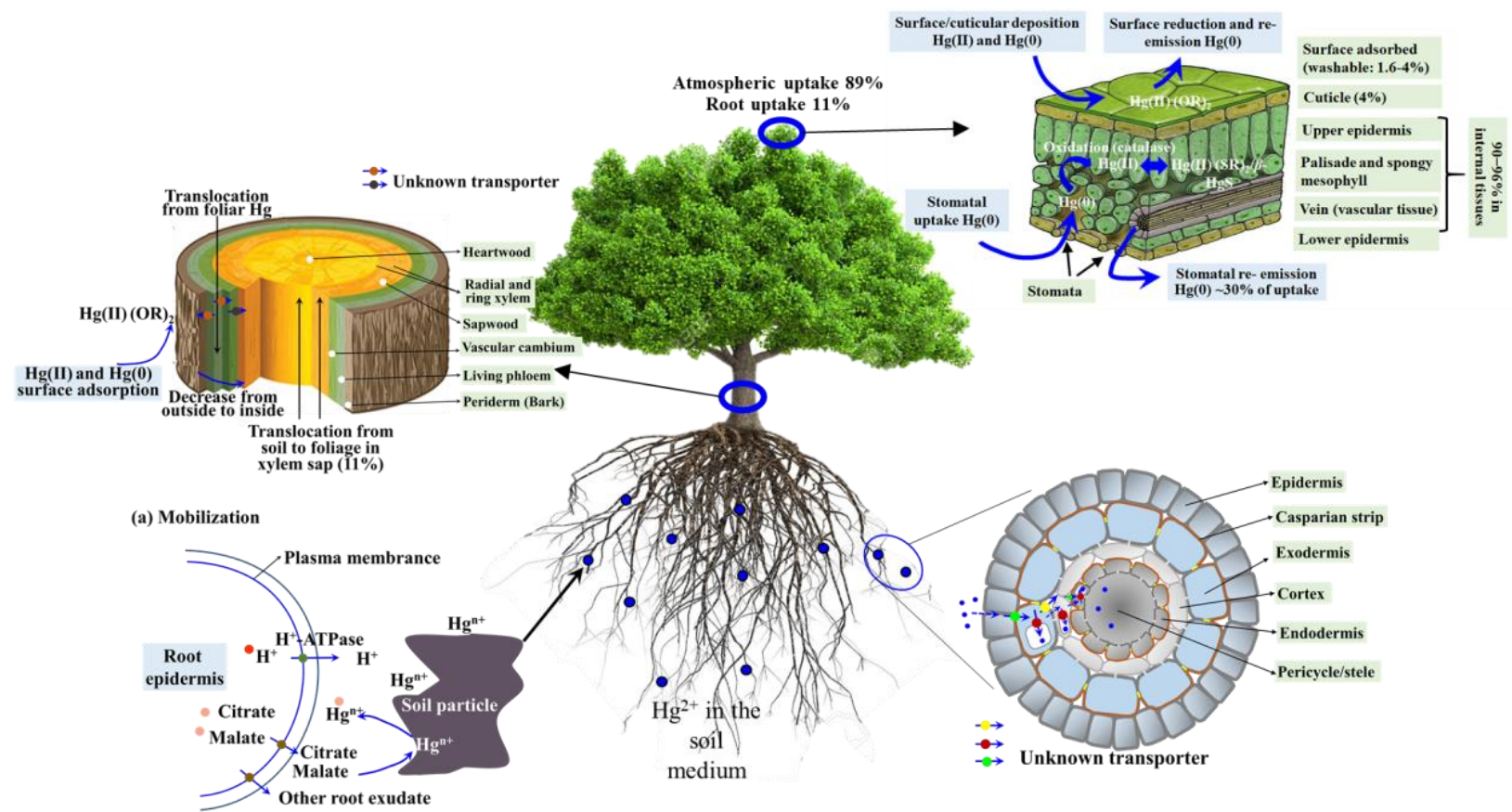

Figure 2. Schematic diagrams of pathways of plant $\mathrm{Hg}$ uptake, including uptake of soil solution $\mathrm{Hg}$ by roots and subsequent transport through root tissues and into xylem; passive uptake of atmospheric $\mathrm{Hg}$ to the bark and transport through bark; and assimilation of atmospheric $\mathrm{Hg}$ by foliage via stomatal and cuticular uptake, along with detailed transport pathway inside leaf tissues and translocation via phloem transport to woody tissues. 

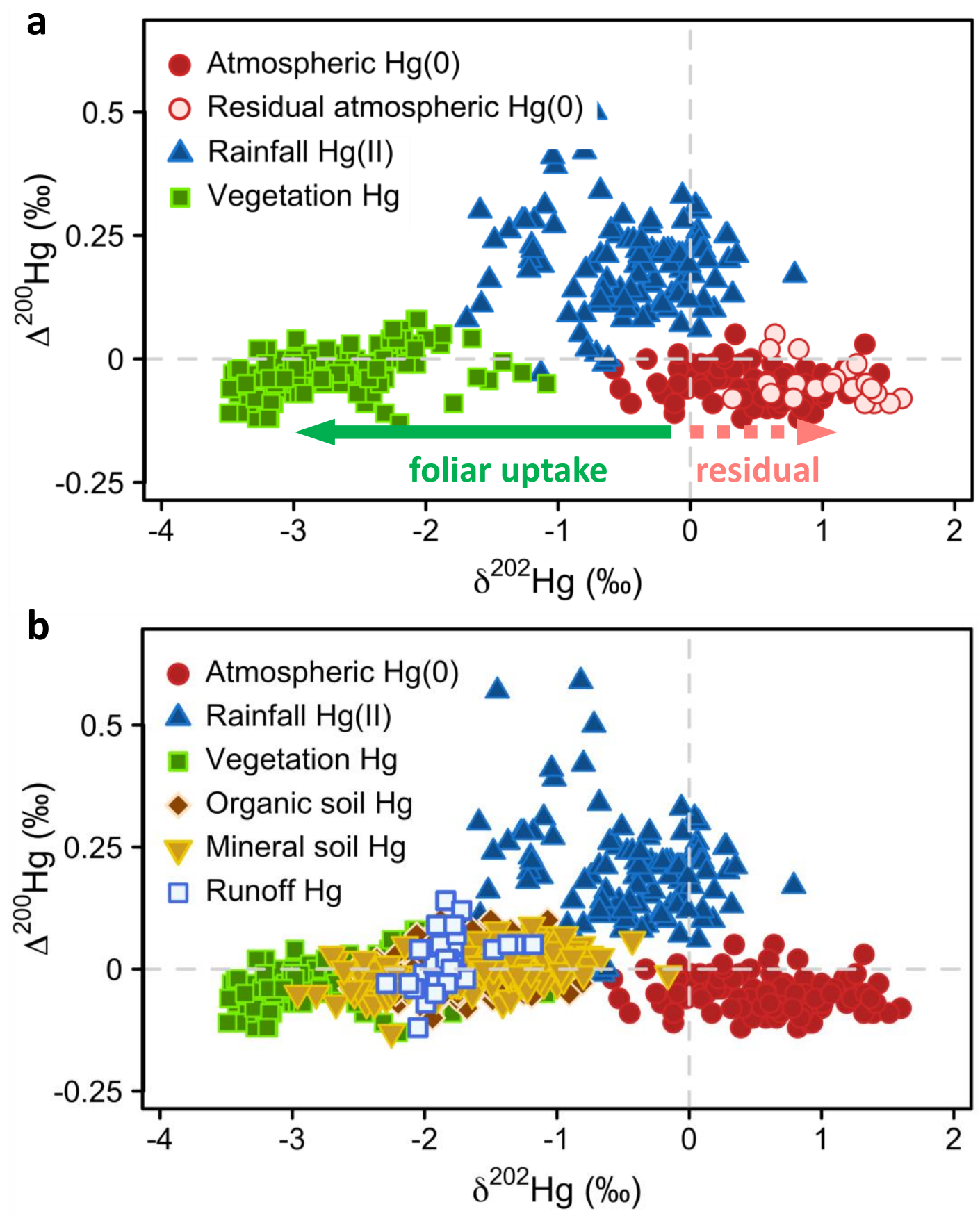


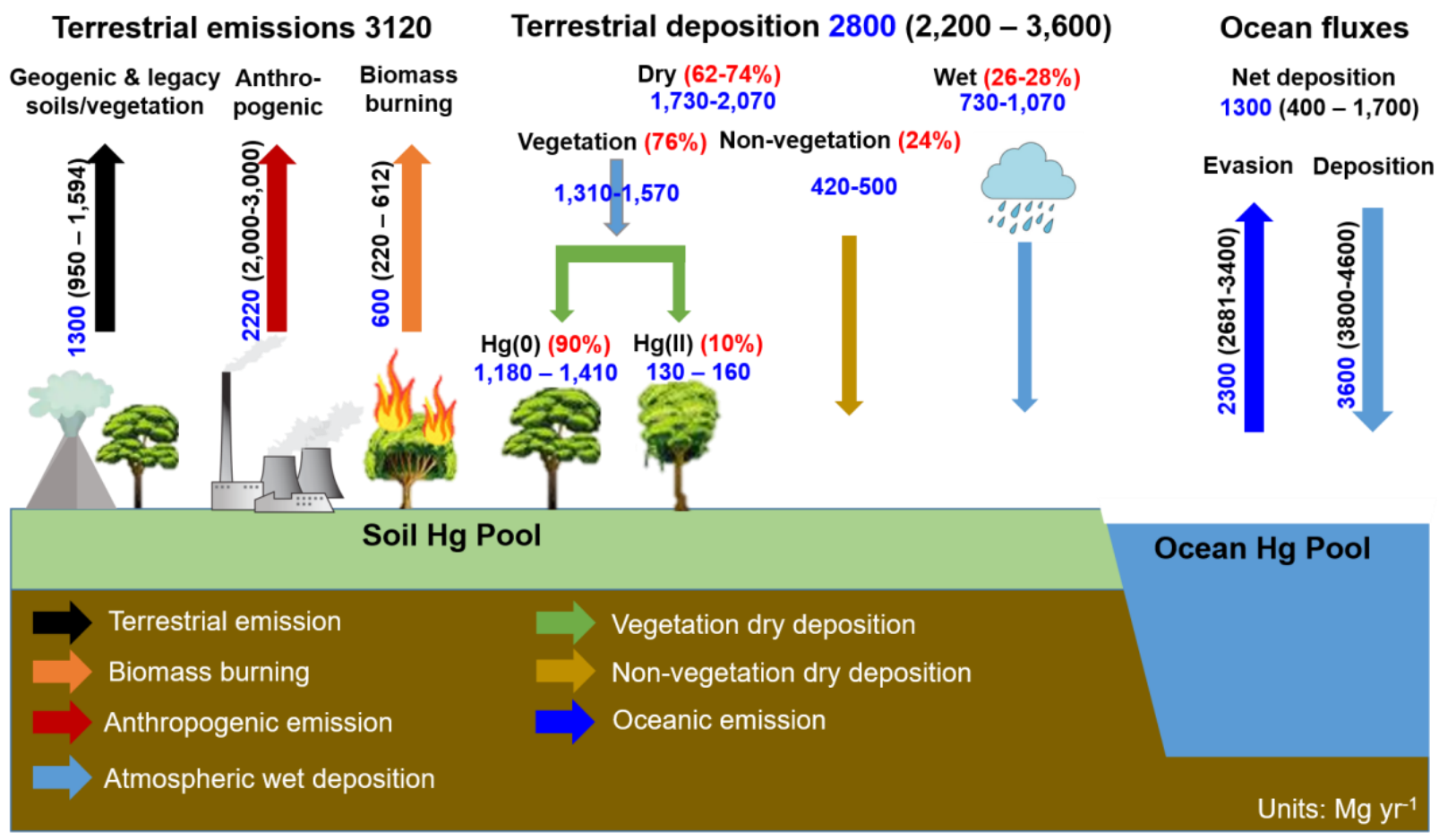

Figure 4. The global geochemical cycle of $\mathrm{Hg}$ with a focus on atmopsheric emissions, transport and deposition. Hg emissions include natural, anthropogenic and legacy sources. Terrestrial deposition includes dry and wet deposition, and dry deposition is separated further into vegetation $\mathrm{Hg}$ uptake $(\mathrm{Hg}(0) \operatorname{and~} \mathrm{Hg}(\mathrm{II}))$ and deposition to non-vegetation surfaces (soils, snow and water) using GEM-MACH-Hg model simulations (this study). GEM-MACH-Hg model estimates are in blue and peer-reviewed literature ranges are in brackets. Origins of literature fluxes are given in Table S1. The units for the emission and deposition

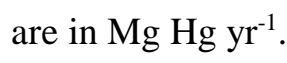



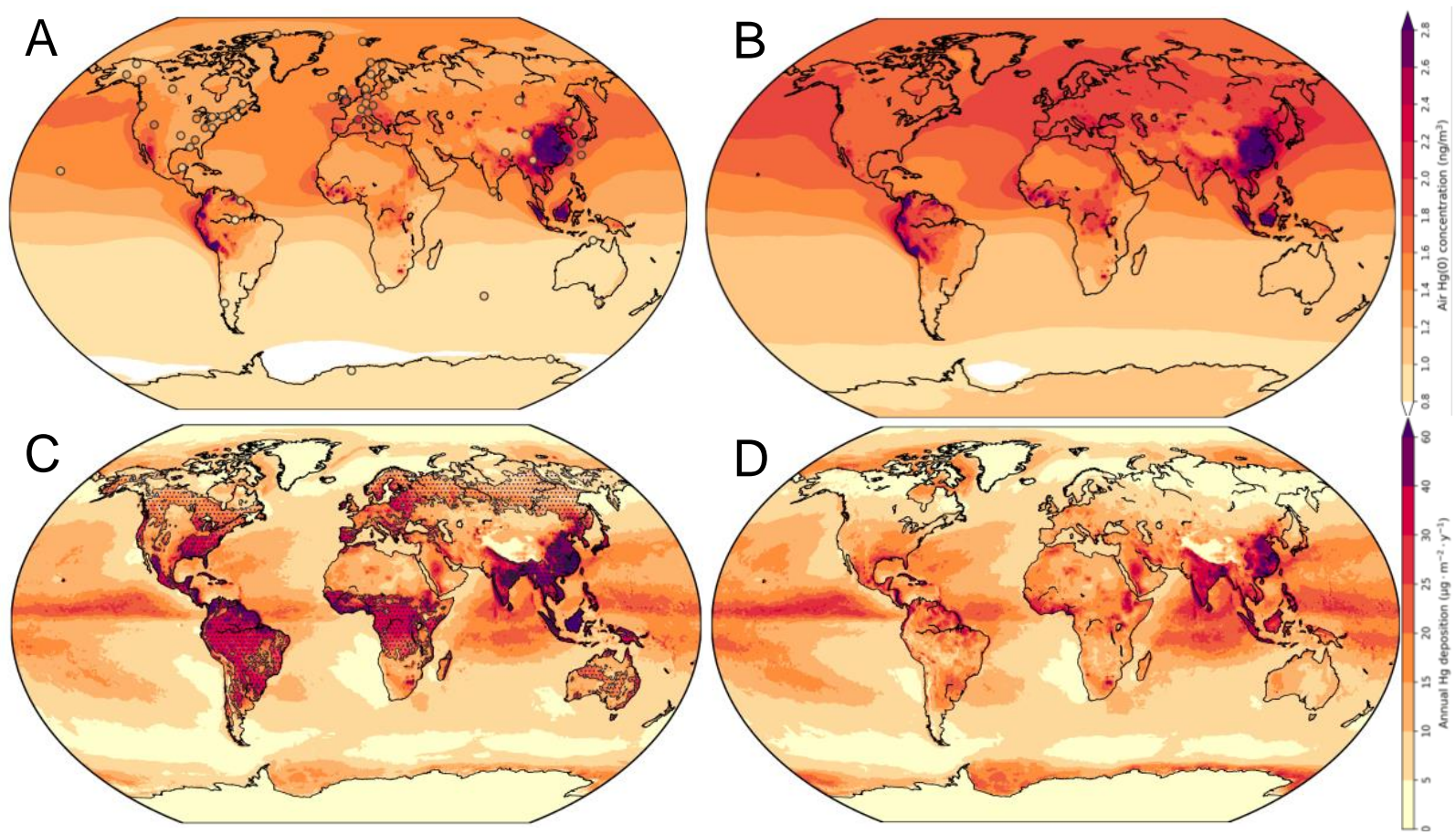

Figure 5. a./b. Global annual average surface air $\mathrm{Hg}(0)$ concentrations simulated by the GEM-MACH-Hg model for the year 2015 with vegetation cover present (a) and with vegetation cover absent (b). c./d. Simulated annual $\mathrm{Hg}$ deposition (total wet and dry deposition) for the year 2015 with vegetation cover present (hatched areas indicate regions of forested vegetation) (c) and with vegetation cover absent (d). Available observations of $\mathrm{Hg}(0)$ concentrations are indicated in circles (a); nearby sites are combined and replaced with median values. References for observations are as follows: CAPMoN, ECCC: Cole et al. (2013) ${ }^{257}$; AMNet: Gay et al. (2013) ${ }^{258}$; EMEP: Tørseth et al. (2012) ${ }^{259}$; GMOS: Sprovieri et al. (2016) ${ }^{260}$; Mace Head: Custodio at al. $(2020)^{261}$; Cape Point and Amsterdam Island: Slemr et al. $(2020)^{262}$; Cape Grim: Slemr et al. (2015) 263 ; Gunn Point: Howard et al. (2017) 264; Mount Lulin: McLagan et al. (2018) ${ }^{265}$. 

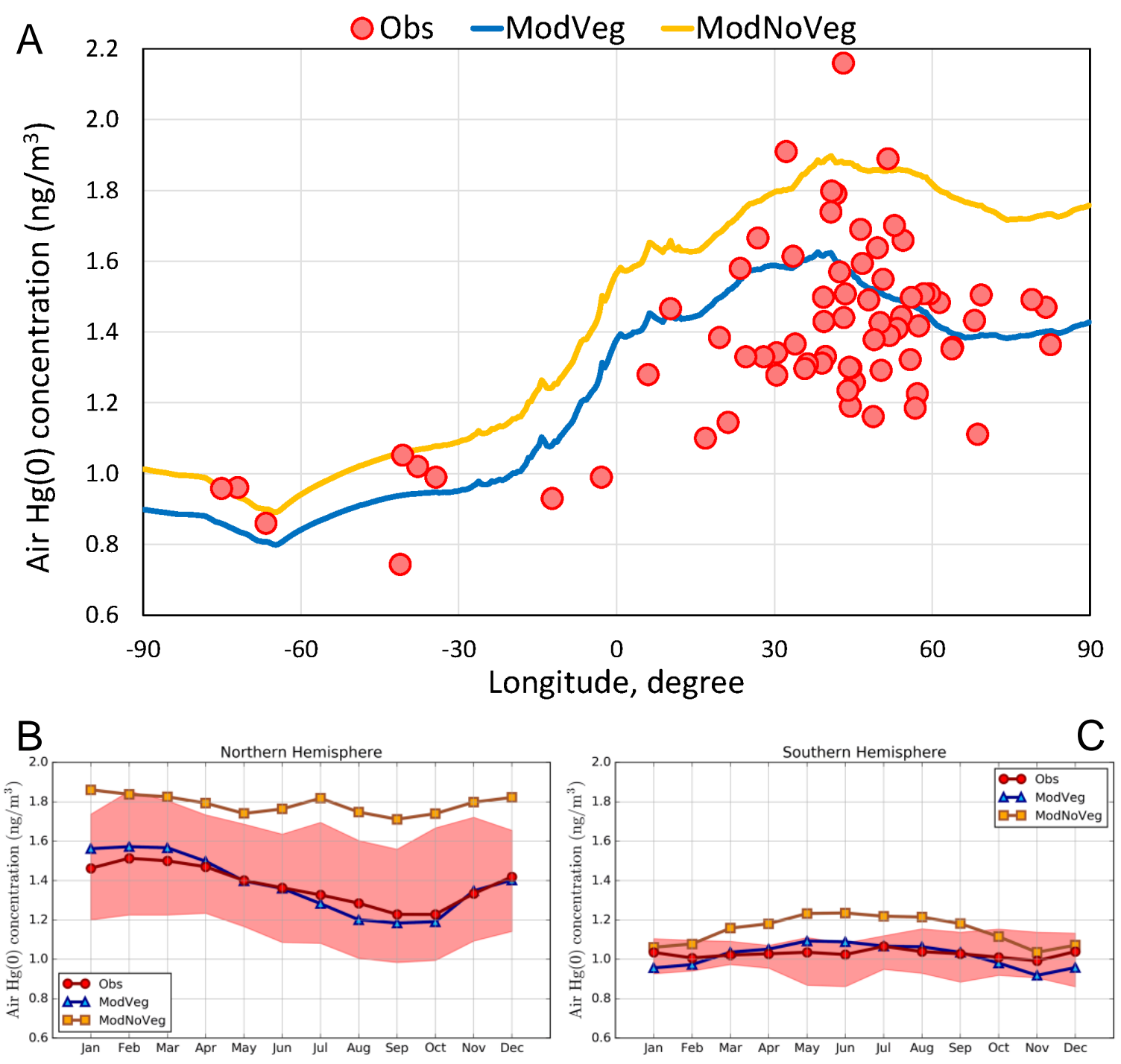

Figure 6. a. Average surface air $\mathrm{Hg}(0)$ concentrations along with the global hemispheric gradient simulated by GEM-MACH-Hg for 2015 with and without vegetation cover present. Blue line represents model simulation with vegetation present, yellow line represents model simulation without vegetation present, and red dots represent measurement observations. Model simulated lines represent averaged $\operatorname{Hg}(0)$ concentrations in $0.5^{\circ}$ latitude bands including oceanic regions; observations represent sites mostly located over land and in North America and Europe. b./c. Average measured and simulated (by the GEM-MACH$\mathrm{Hg}$ model at the observation sites) seasonal cycles of surface air $\mathrm{Hg}(0)$ concentrations in northern and southern hemispheres; coastal and urban sites were excluding from averaging in northern hemisphere; southern hemisphere seasonal cycle is the average of two sites, Cape Point and Amsterdam Island. Blue and yellow lines represent model simulations with vegetation present and without vegetation present, respectively, for 2015. Red lines and shaded areas represent median of available measurements between 2009-2018 and $5^{\text {th }}-95^{\text {th }}$ percentiles, respectively. 


\section{References:}

1 Selin, H. et al. Linking science and policy to support the implementation of the Minamata Convention on Mercury. Ambio 47, 198-215 (2018).

2 Obrist, D. et al. A review of global environmental mercury processes in response to human and natural perturbations: Changes of emissions, climate, and land use. Ambio 47, 116-140, doi:10.1007/s13280017-1004-9 (2018).

3 Programme, U. N. E. (United Nations Environment Programme, Chemicals and Health Branch Geneva ..., 2019).

4 Horowitz, H. M. et al. A new mechanism for atmospheric mercury redox chemistry: implications for the global mercury budget. Atmospheric Chemistry and Physics 17, 6353-6371, doi:10.5194/acp-176353-2017 (2017).

5 Kumar, A., Wu, S., Huang, Y., Liao, H. \& Kaplan, J. O. Mercury from wildfires: Global emission inventories and sensitivity to 2000-2050 global change. Atmos Environ 173, 6-15, doi:https://doi.org/10.1016/i.atmosenv.2017.10.061 (2018).

6 Outridge, P. M., Mason, R. P., Wang, F., Guerrero, S. \& Heimburger-Boavida, L. E. Updated global and oceanic mercury budgets for the united nations global mercury assessment 2018. Environmental Science \& Technology 52, 11466-11477, doi:10.1021/acs.est.8b01246 (2018).

7 Cohen, M. D. et al. Modeling the global atmospheric transport and deposition of mercury to the Great Lakes. Elementa-Science of the Anthropocene 4, doi:10.12952/journal.elementa.000118 (2016).

8 Song, S. et al. Top-down constraints on atmospheric mercury emissions and implications for global biogeochemical cycling. Atmos Chem Phys 15, 7103-7125, doi:10.5194/acp-15-7103-2015 (2015).

9 Zhang, Y. et al. A coupled global atmosphere-ocean model for air-sea exchange of mercury: Insights into wet deposition and atmospheric redox chemistry. Environmental science \& technology 53, 50525061 (2019).

10 Obrist, D. et al. Tundra uptake of atmospheric elemental mercury drives Arctic mercury pollution. Nature 547, 201-204 (2017).

11 Mao, H., Cheng, I. \& Zhang, L. Current understanding of the driving mechanisms for spatiotemporal variations of atmospheric speciated mercury: a review. Atmospheric Chemistry and Physics 16, $12897-$ 12924, doi:10.5194/acp-16-12897-2016 (2016).

12 Iverfeldt, $\AA$. Mercury in forest canopy throughfall water and its relation to atmospheric deposition. Water, Air, and Soil Pollution 56, 553-564 (1991).

13 Munthe, J., Hultberg, H. \& Iverfeldt, A. Mechanisms of deposition of methylmercury and mercury to coniferous forests. Water Air Soil Poll 80, 363-371, doi:10.1007/bf01189686 (1995).

14 Niu, Z. C., Zhang, X. S., Wang, Z. W. \& Ci, Z. J. Field controlled experiments of mercury accumulation in crops from air and soil. Environ Pollut 159, 2684-2689, doi:10.1016/j.envpol.2011.05.029 (2011).

15 Wang, J., Feng, X., Anderson, C. W., Xing, Y. \& Shang, L. Remediation of mercury contaminated sites - A review. J Hazard Mater 221-222, 1-18, doi:10.1016/j.jhazmat.2012.04.035 (2012).

16 Ranieri, E. et al. Phytoextraction technologies for mercury- and chromium-contaminated soil: a review. Journal of Chemical Technology and Biotechnology 95, 317-327, doi:10.1002/jctb.6008 (2020).

17 Grigal, D., Kolka, R., Fleck, J. \& Nater, E. Mercury budget of an upland-peatland watershed. Biogeochemistry 50, 95-109 (2000).

18 Grigal, D. F. Mercury sequestration in forests and peatlands: A review. J Environ Qual 32, 393-405 (2003).

19 St. Louis, V. et al. Importance of the forest canopy to fluxes of methyl mercury and total mercury to boreal ecosystems. Environ Sci Technol 35, 3089-3098 (2001).

20 Jiskra, M., Sonke, J. E., Agnan, Y., Helmig, D. \& Obrist, D. Insights from mercury stable isotopes on terrestrial-atmosphere exchange of $\mathrm{Hg}(0)$ in the Arctic tundra. Biogeosciences 16, 4051-4064, doi:10.5194/bg-16-4051-2019 (2019). 
21 Uprety, S. \& Cao, C. Radiometric comparison of 1.6-mu m CO2 absorption band of greenhouse gases observing satellite (GOSAT) TANSO-FTS with suomi-NPP VIIRS SWIR band. Journal of Atmospheric and Oceanic Technology 33, 1443-1453, doi:10.1175/jtech-d-15-0157.1 (2016).

22 Jiskra, M. et al. A vegetation control on seasonal variations in global atmospheric mercury concentrations. Nat Geosci 11, 244-250 (2018).

23 Obrist, D. et al. A synthesis of terrestrial mercury in the western United States: Spatial distribution defined by land cover and plant productivity. Science of the Total Environment 568, 522-535, doi:10.1016/j.scitotenv.2015.11.104 (2016).

24 Obrist, D. Mercury distribution across 14 U.S. forests. Part II: Patterns of methyl mercury concentrations and areal mass of total and methyl mercury. Environ. Sci. Technol. 46, 5921-5930 (2012).

25 Obrist, D. et al. Mercury distribution across 14 U.S. forests. Part I: Spatial patterns of concentrations in biomass, litter, and soils. Environ Sci Technol 45, 3974-3981 (2011).

26 Evers, D. C. et al. Biological mercury hotspots in the northeastern United States and southeastern Canada. Bioscience 57, 29-43 (2007).

27 Driscoll, C. T. et al. Mercury contamination in forest and freshwater ecosystems in the Northeastern United States. Bioscience 57, 17-28 (2007).

28 Fleck, J. A. et al. Mercury and methylmercury in aquatic sediment across western North America. Science of the Total Environment 568, 727-738, doi:10.1016/j.scitotenv.2016.03.044 (2016).

29 Hsu-Kim, H. et al. Challenges and opportunities for managing aquatic mercury pollution in altered landscapes. Ambio 47, 141-169, doi:10.1007/s13280-017-1006-7 (2018).

30 Shanley, J. B. et al. Comparison of total mercury and methylmercury cycling at five sites using the small watershed approach. Environmental Pollution 154, 143-154, doi:10.1016/j.envpol.2007.12.031 (2008).

31 Riscassi, A. L. \& Scanlon, T. M. Particulate and dissolved mercury export in streamwater within three mid-Appalachian forested watersheds in the US. Journal of Hydrology 501, 92-100, doi:10.1016/j.jhydrol.2013.07.041 (2013).

32 Sonke, J. E. et al. Eurasian river spring flood observations support net Arctic Ocean mercury export to the atmosphere and Atlantic Ocean. $P$ Natl Acad Sci USA 115, E11586-E11594, doi:10.1073/pnas.1811957115 (2018).

33 Douglas, T. A. \& Blum, J. D. Mercury isotopes reveal atmospheric gaseous mercury deposition directly to the Arctic coastal snowpack. Environmental Science \& Technology Letters 6, 235-242, doi:10.1021/acs.estlett.9b00131 (2019).

34 Strok, M., Baya, P. A., Dietrich, D., Dimock, B. \& Hintelmann, H. Mercury speciation and mercury stable isotope composition in sediments from the Canadian Arctic Archipelago. Sci Total Environ 671, 655-665, doi:10.1016/j.scitotenv.2019.03.424 (2019).

35 Jiskra, M., Wiederhold, J. G., Skyllberg, U., Kronberg, R.-M. \& Kretzschmar, R. Source tracing of natural organic matter bound mercury in boreal forest runoff with mercury stable isotopes. Environmental Science: Processes \& Impacts 19, 1235-1248 (2017).

36 Janssen, S. et al. Chemical and Physical Controls on Mercury Source Signatures in Stream Fish from the Northeastern United States. Environ Sci Technol 53, doi:10.1021/acs.est.9b03394 (2019).

37 Madigan, D. et al. Mercury Stable Isotopes Reveal Influence of Foraging Depth on Mercury Concentrations and Growth in Pacific Bluefin Tuna. Environ Sci Technol 52, doi:10.1021/acs.est.7b06429 (2018).

$38 \mathrm{Li}, \mathrm{M}$. et al. Environmental origins of methylmercury accumulated in subarctic estuarine fish indicated by mercury stable isotopes. Environmental Science \& Technology 50, 11559-11568, doi:10.1021/acs.est.6b03206 (2016).

39 Dastoor, A. et al. Atmospheric mercury in the Canadian Arctic. Part II: Insight from modeling. Science of the Total Environment 509, 16-27, doi:10.1016/j.scitotenv.2014.10.112 (2015).

40 Dastoor, A. P. \& Durnford, D. A. Arctic Ocean: Is it a sink or a source of atmospheric mercury? Environmental science \& technology 48, 1707-1717 (2014). 
41 Dastoor, A. P. et al. Modeling dynamic exchange of gaseous elemental mercury at polar sunrise. Environmental Science \& Technology 42, 5183-5188, doi:10.1021/es800291w (2008).

42 Kos, G. et al. Evaluation of discrepancy between measured and modelled oxidized mercury species. Atmospheric Chemistry and Physics 13, 4839-4863, doi:10.5194/acp-13-4839-2013 (2013).

43 Arnold, J., Gustin, M. S. \& Weisberg, P. J. Evidence for nonstomatal uptake of Hg by aspen and translocation of $\mathrm{Hg}$ from foliage to tree rings in Austrian pine. Environmental Science \& Technology 52, 1174-1182, doi:10.1021/acs.est.7b04468 (2018).

44 Peckham, M. A., Gustin, M. S., Weisberg, P. J. \& Weiss-Penzias, P. Results of a controlled field experiment to assess the use of tree tissue concentrations as bioindicators of air $\mathrm{Hg}$. Biogeochemistry 142, 265-279, doi:10.1007/s10533-018-0533-z (2019).

45 Greger, M., Wang, Y. D. \& Neuschutz, C. Absence of Hg transpiration by shoot after Hg uptake by roots of six terrestrial plant species. Environ Pollut 134, 201-208, doi:10.1016/j.envpol.2004.08.007 (2005).

46 Stamenkovic, J. \& Gustin, M. S. Nonstomatal versus Stomatal Uptake of Atmospheric Mercury. Environmental Science \& Technology 43, 1367-1372, doi:10.1021/es801583a (2009).

47 Chiarantini, L. et al. Black pine (Pinus nigra) barks as biomonitors of airborne mercury pollution. Sci Total Environ 569, 105-113, doi:10.1016/j.scitotenv.2016.06.029 (2016).

48 Cocking, D., Rohrer, M., Thomas, R., Walker, J. \& Ward, D. Effects of root morphology and Hg concentration in the soil on uptake by terrestrial vascular plants. Water Air Soil Poll 80, 1113-1116, doi:10.1007/bf01189773 (1995).

49 Juillerat, J. I., Ross, D. S. \& Bank, M. S. Mercury in litterfall and upper soil horizons in forested ecosystems in Vermont, USA. Environ Toxicol Chem 31, 1720-1729, doi:Doi 10.1002/Etc.1896 (2012).

50 Obrist, D., Johnson, D. W. \& Edmonds, R. L. Effects of vegetation type on mercury concentrations and pools in two adjacent coniferous and deciduous forests. Journal of Plant Nutrition and Soil Science 175, 68-77, doi:10.1002/jpln.201000415 (2012).

51 Laacouri, A., Nater, E. A. \& Kolka, R. K. Distribution and Uptake Dynamics of Mercury in Leaves of Common Deciduous Tree Species in Minnesota, USA. Environ Sci Technol 47, 10462-10470, doi:Doi 10.1021/Es401357z (2013).

52 Lodenius, A., Tulisalo, E. \& Soltanpour-Gargari, A. Exchange of mercury between atmosphere and vegetation under contaminated conditions. Sci Total Environ 304, 169-174, doi:10.1016/s00489697(02)00566-1 (2003).

53 Fay, L. \& Gustin, M. Assessing the influence of different atmospheric and soil mercury concentrations on foliar mercury concentrations in a controlled environment. Water Air Soil Poll 181, 373-384, doi:10.1007/s11270-006-9308-6 (2007).

54 Niu, Z. et al. Field controlled experiments on the physiological responses of maize (Zea mays L.) leaves to low-level air and soil mercury exposures. Environ Sci Pollut $R$ 21, 1541-1547, doi:10.1007/s11356-013-2047-5 (2014).

55 Assad, M. et al. Mercury uptake into poplar leaves. Chemosphere 146, 1-7, doi:10.1016/j.chemosphere.2015.11.103 (2016).

56 Millhollen, A. G., Gustin, M. S. \& Obrist, D. Foliar mercury accumulation and exchange for three tree species. Environ Sci Technol 40, 6001-6006, doi:10.1021/es0609194 (2006).

57 Mao, Y., Li, Y., Richards, J. \& Cai, Y. Investigating Uptake and Translocation of Mercury Species by Sawgrass (Cladium jamaicense) Using a Stable Isotope Tracer Technique. Environ Sci Technol 47, 9678-9684, doi:10.1021/es400546s (2013).

58 Graydon, J. A. et al. Investigation of Uptake and Retention of Atmospheric $\mathrm{Hg}$ (II) by Boreal Forest Plants Using Stable Hg Isotopes. Environ Sci Technol 43, 4960-4966 (2009).

59 Cui, L. W. et al. Accumulation and translocation of (198) Hg in four crop species. Environ Toxicol Chem 33, 334-340, doi:10.1002/etc.2443 (2014).

60 Yuan, W. et al. Stable isotope evidence shows re-emission of elemental mercury vapor occurring after reductive loss from foliage. Environ Sci Technol 53, 651-660, doi:10.1021/acs.est.8b04865 (2019). 
61 Olson, C. L., Jiskra, M., Sonke, J. E. \& Obrist, D. Mercury in tundra vegetation of Alaska: Spatial and temporal dynamics and stable isotope patterns. Science of the Total Environment 660, 1502-1512 (2019).

62 Sun, L., Lu, B., Yuan, D., Hao, W. \& Zheng, Y. Variations in the isotopic composition of stable mercury isotopes in typical mangrove plants of the Jiulong estuary, SE China. Environ Sci Pollut $R$ 24, 1459-1468, doi:10.1007/s11356-016-7933-1 (2017).

63 Graydon, J. A. et al. The role of terrestrial vegetation in atmospheric Hg deposition: Pools and fluxes of spike and ambient $\mathrm{Hg}$ from the METAALICUS experiment. Global Biogeochemical Cycles 26, doi:10.1029/2011gb004031 (2012).

64 Rutter, A. P. et al. Dry deposition of gaseous elemental mercury to plants and soils using mercury stable isotopes in a controlled environment. Atmospheric Environment 45, 848-855, doi:10.1016/j.atmosenv.2010.11.025 (2011).

65 Bishop, K. H., Lee, Y. H., Munthe, J. \& Dambrine, E. Xylem sap as a pathway for total mercury and methylmercury transport from soils to tree canopy in the boreal forest. Biogeochemistry 40, 101-113, doi:10.1023/a:1005983932240 (1998).

66 Beauford, W., Barber, J. \& Barringer, A. Uptake and distribution of mercury within higher plants. Physiologia Plantarum 39, 261-265 (1977).

67 Cavallini, A., Natali, L., Durante, M. \& Maserti, B. Mercury uptake, distribution and DNA affinity in durum wheat (Triticum durum Desf.) plants. Sci Total Environ 243, 119-127, doi:10.1016/S00489697(99)00367-8 (1999).

68 Blackwell, B. D. \& Driscoll, C. T. Using foliar and forest floor mercury concentrations to assess spatial patterns of mercury deposition. Environ Pollut 202, 126-134, doi:10.1016/j.envpol.2015.02.036 (2015).

69 Amado Filho, G. M., Andrade, L. R., Farina, M. \& Malm, O. Hg localisation in Tillandsia usneoides L. (Bromeliaceae), an atmospheric biomonitor. Atmos Environ 36, 881-887, doi:10.1016/S13522310(01)00496-4 (2002).

70 Du, S.-H. \& Fang, S. C. Catalase activity of C3 and C4 species and its relationship to mercury vapor uptake. Environmental and Experimental Botany 23, 347-353, doi:http://dx.doi.org/10.1016/00988472(83)90009-6 (1983).

71 Leonard, T. L., Taylor, G. E., Gustin, M. S. \& Fernandez, G. C. J. Mercury and plants in contaminated soils: 1. Uptake, partitioning, and emission to the atmosphere. Environ Toxicol Chem 17, 2063-2071, doi:10.1002/etc.5620171024 (1998).

72 Converse, A. D., Riscassi, A. L. \& Scanlon, T. M. Seasonal variability in gaseous mercury fluxes measured in a high-elevation meadow. Atmos Environ 44, 2176-2185, doi:10.1016/j.atmosenv.2010.03.024 (2010).

73 Fritsche, J. et al. Elemental mercury fluxes over a sub-alpine grassland determined with two micrometeorological methods. Atmos Environ 42, 2922-2933, doi:10.1016/j.atmosenv.2007.12.055 (2008).

$74 \mathrm{Fu}, \mathrm{X}$. et al. Depletion of atmospheric gaseous elemental mercury by plant uptake at Mt. Changbai, Northeast China. Atmospheric Chemistry and Physics 16, 12861-12873, doi:10.5194/acp-16-128612016 (2016).

75 Manceau, A., Wang, J., Rovezzi, M., Glatzel, P. \& Feng, X. Biogenesis of mercury-sulfur nanoparticles in plant leaves from atmospheric gaseous mercury. Environ Sci Technol 52, 3935-3948 (2018).

76 Carrasco-Gil, S. et al. Mercury localization and speciation in plants grown hydroponically or in a natural environment. Environ Sci Technol 47, 3082-3090 (2013).

77 Carrasco-Gil, S. et al. Complexation of $\mathrm{Hg}$ with phytochelatins is important for plant $\mathrm{Hg}$ tolerance. Plant, cell \& environment 34, 778-791 (2011). 
78 Niu, Z. et al. The linear accumulation of atmospheric mercury by vegetable and grass leaves: Potential biomonitors for atmospheric mercury pollution. Environ Sci Pollut $R$ 20, 6337-6343, doi:10.1007/s11356-013-1691-0 (2013).

79 Frescholtz, T. F., Gustin, M. S., Schorran, D. E. \& Fernandez, G. C. J. Assessing the source of mercury in foliar tissue of quaking aspen. Environ Toxicol Chem 22, 2114-2119 (2003).

80 Zhou, J. et al. Mercury fluxes, budgets, and pools in forest ecosystems of China: A review. Critical Reviews in Environmental Science and Technology 50, 1411-1450, doi:10.1080/10643389.2019.1661176 (2020).

81 Gunda, T. \& Scanlon, T. M. Topographical influences on the spatial distribution of soil mercury at the catchment scale. Water, Air, \& Soil Pollution 224, 1511 (2013).

82 Lindberg, S. E., Hanson, P. J., Meyers, T. P. \& Kim, K. H. Air/surface exchange of mercury vapor over forests - The need for a reassessment of continental biogenic emissions. Atmos Environ 32, 895908, doi:10.1016/s1352-2310(97)00173-8 (1998).

83 Poissant, L., Pilote, M., Yumvihoze, E. \& Lean, D. Mercury concentrations and foliage/atmosphere fluxes in a maple forest ecosystem in Quebec, Canada. $J$ Geophys Res-Atmos 113, doi:10.1029/2007jd009510 (2008).

84 Ericksen, J. A. \& Gustin, M. S. Foliar exchange of mercury as a function of soil and air mercury concentrations. Sci Total Environ 324, 271-279, doi:10.1016/j.scitotenv.2003.10.034 (2004).

85 Luo, Y. et al. Foliage/atmosphere exchange of mercury in a subtropical coniferous forest in south China. J Geophys Res-Biogeo 121, 2006-2016, doi:10.1002/2016jg003388 (2016).

86 Teixeira, D. C., Lacerda, L. D. \& Silva-Filho, E. V. Foliar mercury content from tropical trees and its correlation with physiological parameters in situ. Environ Pollut 242, 1050-1057, doi:10.1016/j.envpol.2018.07.120 (2018).

87 Bacci, E., Gaggi, C., Duccini, M., Bargagli, R. \& Renzoni, A. Mapping mercury vapours in an abandoned cinnabar mining area by azalea (Azalea indica) leaf trapping. Chemosphere 29, 641-656, doi:https://doi.org/10.1016/0045-6535(94)90036-1 (1994).

$88 \mathrm{Du}, \mathrm{S}$. H. \& Fang, S. C. Uptake of elemental mercury-vapor by C3-species and C4-species. Environmental and Experimental Botany 22, 437-443, doi:10.1016/0098-8472(82)90054-5 (1982).

89 Battke, F., Ernst, D., Fleischmann, F. \& Halbach, S. Phytoreduction and volatilization of mercury by ascorbate in Arabidopsis thaliana, European beech and Norway spruce. Appl Geochem 23, 494-502, doi:10.1016/j.apgeochem.2007.12.023 (2008).

90 Wohlgemuth, L. et al. A bottom-up quantification of foliar mercury uptake fluxes across Europe. Biogeosciences Discussion 2020, 1-25, doi:10.5194/bg-2020-289 (2020).

91 Ollerova, H., Maruskova, A., Kontrisova, O. \& Pliestikova, L. Mercury Accumulation in Picea abies (L.) Karst. Needles with Regard to Needle Age. Polish Journal of Environmental Studies 19, 14011404 (2010).

92 Hutnik, R. J., McClenahen, J. R., Long, R. P. \& Davis, D. D. Mercury Accumulation in Pinus nigra (Austrian Pine). Northeastern Naturalist 21, 529-540, doi:10.1656/045.021.0402 (2014).

93 Navratil, T. et al. Decreasing litterfall mercury deposition in central European coniferous forests and effects of bark beetle infestation. Science of the Total Environment 682, 213-225, doi:10.1016/j.scitotenv.2019.05.093 (2019).

94 Hall, B. D. \& Louis, V. L. S. Methylmercury and total mercury in plant litter decomposing in upland forests and flooded landscapes. Environ Sci Technol 38, 5010-5021, doi:10.1021/es049800q (2004).

95 Rasmussen, P. E., Mierle, G. \& Nriagu, J. O. The analysis of vegetation for total mercury. Water Air and Soil Pollution 56, 379-390, doi:10.1007/bf00342285 (1991).

96 Zhang, H. H., Poissant, L., Xu, X. H. \& Pilote, M. Explorative and innovative dynamic flux bag method development and testing for mercury air-vegetation gas exchange fluxes. Atmos Environ 39, 7481-7493, doi:10.1016/j.atmosenv.2005.07.068 (2005).

97 Zhou, J., Wang, Z. W., Sun, T., Zhang, H. \& Zhang, X. S. Mercury in terrestrial forested systems with highly elevated mercury deposition in southwestern China: The risk to insects and potential release from wildfires. Environ Pollut 212, 188-196, doi:10.1016/j.envpol.2016.01.003 (2016). 
98 Clackett, S. P., Porter, T. J. \& Lehnherr, I. 400-year record of atmospheric mercury from tree-rings in Northwestern Canada. Environ Sci Technol 52, 9625-9633, doi:10.1021/acs.est.8b01824 (2018).

99 Jung, R. \& Ahn, Y. S. Distribution of mercury concentrations in tree rings and surface soils adjacent to a phosphate fertilizer plant in Southern Korea. Bulletin of Environmental Contamination and Toxicology 99, 253-257, doi:10.1007/s00128-017-2115-5 (2017).

$100 \mathrm{Kang}, \mathrm{H}$. H. et al. Characterization of mercury concentration from soils to needle and tree rings of Schrenk spruce (Picea schrenkiana) of the middle Tianshan Mountains, northwestern China. Ecol Indic 104, 24-31, doi:10.1016/j.ecolind.2019.04.066 (2019).

101 Navratil, T. et al. Larch Tree Rings as a Tool for Reconstructing 20th Century Central European Atmospheric Mercury Trends. Environ Sci Technol 52, 11060-11068, doi:10.1021/acs.est.8b02117 (2018).

102 Navratil, T. et al. The history of mercury pollution near the Spolana chlor-alkali plant (Neratovice, Czech Republic) as recorded by Scots pine tree rings and other bioindicators. Sci Total Environ 586, 1182-1192, doi:10.1016/j.scitotenv.2017.02.112 (2017).

103 Schneider, L., Allen, K., Walker, M., Morgan, C. \& Haberle, S. Using tree rings to track atmospheric mercury pollution in australia: The legacy of mining in Tasmania. Environ Sci Technol 53, 5697-5706, doi:10.1021/acs.est.8b06712 (2019).

104 Wright, G., Woodward, C., Peri, L., Weisberg, P. J. \& Gustin, M. S. Application of tree rings dendrochemistry for detecting historical trends in air $\mathrm{Hg}$ concentrations across multiple scales. Biogeochemistry 120, 149-162, doi:10.1007/s10533-014-9987-9 (2014).

105 Hojdova, M. et al. Changes in mercury deposition in a mining and smelting region as recorded in tree rings. Water Air Soil Poll 216, 73-82, doi:10.1007/s11270-010-0515-9 (2011).

106 Tangahu, B. V. et al. A review on heavy metals (As, $\mathrm{Pb}$, and $\mathrm{Hg}$ ) uptake by plants through phytoremediation. International Journal of Chemical Engineering 2011 (2011).

107 Farella, N., Lucotte, M., Davidson, R. \& Daigle, S. Mercury release from deforested soils triggered by base cation enrichment. Science of the Total Environment 368, 19-29 (2006).

108 Clemens, S. Toxic metal accumulation, responses to exposure and mechanisms of tolerance in plants. Biochimie 88, 1707-1719 (2006).

109 Clemens, S. \& Ma, J. F. Toxic Heavy Metal and Metalloid Accumulation in Crop Plants and Foods. Annual review of plant biology 67, 489-512, doi:10.1146/annurev-arplant-043015-112301 (2016).

110 Park, J. et al. The phytochelatin transporters AtABCC1 and AtABCC2 mediate tolerance to cadmium and mercury. The Plant Journal 69, 278-288 (2012).

111 Wang, J. J. et al. Fine Root Mercury Heterogeneity: Metabolism of Lower-Order Roots as an Effective Route for Mercury Removal. Environmental Science \& Technology 46, 769-777, doi:10.1021/es2018708 (2012).

112 Zhou, J. et al. Influence of soil mercury concentration and fraction on bioaccumulation process of inorganic mercury and methylmercury in rice (Oryza sativa L.). Environmental Science and Pollution Research 22, 6144-6154 (2015).

113 Yin, R., Feng, X. \& Meng, B. Stable mercury isotope variation in rice plants (Oryza sativa L.) from the Wanshan mercury mining district, SW China. Environmental science \& technology 47, 2238-2245 (2013).

114 Wang, X. et al. Underestimated sink of atmospheric mercury in a deglaciated forest chronosequence. Environmental Science \& Technology 54, 8083-8093, doi:10.1021/acs.est.0c01667 (2020).

115 Rewald, B., Ephrath, J. E. \& Rachmilevitch, S. A root is a root is a root? Water uptake rates of Citrus root orders. Plant, cell \& environment 34, 33-42 (2011).

116 Bargagli, R. Moss and lichen biomonitoring of atmospheric mercury: A review. Sci Total Environ 572, 216-231, doi:10.1016/j.scitotenv.2016.07.202 (2016).

117 Adamo, P. et al. Natural and pre-treatments induced variability in the chemical composition and morphology of lichens and mosses selected for active monitoring of airborne elements. Environmental Pollution 152, 11-19, doi:10.1016/j.envpol.2007.06.008 (2008). 
118 Bargagli, R. The elemental composition of vegetation and the possible incidence of soil contamination of samples. Science of the Total Environment 176, 121-128, doi:10.1016/0048-9697(95)04838-3 (1995).

119 Bargagli, R. \& Mikhailova, I. in Monitoring with Lichens - Monitoring Lichens Vol. 7 NATO Science Series IV Earth and Environmental Sciences (eds P. L. Nimis, C. Scheidegger, \& P. A. Wolseley) 6584 (2002).

120 Dolegowska, S. \& Migaszewski, Z. M. Plant sampling uncertainty: a critical review based on moss studies. Environ Rev 23, 151-160, doi:10.1139/er-2014-0052 (2015).

121 Tyler, G. Bryophytes and heavy-metals - a literature-review. Botanical Journal of the Linnean Society 104, 231-253, doi:10.1111/j.1095-8339.1990.tb02220.x (1990).

122 Stankovic, J. D., Sabovljevic, A. D. \& Sabovljevic, M. S. Bryophytes and heavy metals: a review. Acta Botanica Croatica 77, 109-118, doi:10.2478/botcro-2018-0014 (2018).

123 Onianwa, P. C. Monitoring atmospheric metal pollution: A review of the use of mosses as indicators. Environ Monit Assess 71, 13-50, doi:10.1023/a:1011660727479 (2001).

124 Wang, X., Yuan, W., Feng, X., Wang, D. \& Luo, J. Moss facilitating mercury, lead and cadmium enhanced accumulation in organic soils over glacial erratic at Mt. Gongga, China. Environ Pollut 254, 112974, doi:10.1016/j.envpol.2019.112974 (2019).

125 Pradhan, A. et al. in International Conference on Materials, Alloys and Experimental Mechanics Vol. 225 IOP Conference Series-Materials Science and Engineering (eds M. M. Noor, V. N. Mani, M. S. Ganesh, \& M. H. Idris) (2017).

126 Vannini, A., Nicolardi, V., Bargagli, R. \& Loppi, S. Estimating atmospheric mercury concentrations with lichens. Environ Sci Technol 48, 8754-8759, doi:10.1021/es500866k (2014).

127 Enrico, M. et al. Atmospheric mercury transfer to peat bogs dominated by gaseous elemental mercury dry deposition. Environmental Science \& Technology 50, 2405-2412, doi:10.1021/acs.est.5b06058 (2016).

128 Ma, J., Hintelmann, H., Kirk, J. \& Muir, D. Mercury and its isotope composition in lichens and sediments from particular pollution source. Geochimica Et Cosmochimica Acta 74, A649-A649 (2010).

129 Balabanova, B., Stafilov, T., Sajn, R. \& Andonovska, K. B. Quantitative assessment of metal elements using moss species as biomonitors in downwind area of lead-zinc mine. Journal of Environmental Science and Health Part a-Toxic/Hazardous Substances \& Environmental Engineering 52, 290-301, doi:10.1080/10934529.2016.1253403 (2017).

130 Lopez Berdonces, M. A., Higueras, P. L., Fernandez-Pascual, M., Borreguero, A. M. \& Carmona, M. The role of native lichens in the biomonitoring of gaseous mercury at contaminated sites. Journal of Environmental Management 186, 207-213, doi:10.1016/j.jenvman.2016.04.047 (2017).

131 Solberg, Y. \& Selmerolsen, A. R. Studies on chemistry of lichens and mosses .17. Mercury content of several lichen and moss species collected in Norway. Bryologist 81, 144-149, doi:10.2307/3242278 (1978).

132 Hauck, M. \& Runge, M. Occurrence of pollution-sensitive epiphytic lichens in woodlands affected by forest decline: a new hypothesis. Flora 194, 159-168, doi:10.1016/s0367-2530(17)30894-0 (1999).

133 Salemaa, M., Derome, J., Helmisaari, H. S., Nieminen, T. \& Vanha-Majamaa, I. Element accumulation in boreal bryophytes, lichens and vascular plants exposed to heavy metal and sulfur deposition in Finland. Sci Total Environ 324, 141-160, doi:10.1016/j.scitotenv.2003.10.025 (2004).

134 Lodenius, M. Dry and wet deposition of mercury near a chlor-alkali plant. Sci Total Environ 213, 5356, doi:10.1016/s0048-9697(98)00073-4 (1998).

135 Zechmeister, H. G., Hohenwallner, D., Riss, A. \& Hanus-Illnar, A. Variations in heavy metal concentrations in the moss species Abietinella abietina (Hedw.) Fleisch according to sampling time, within site variability and increase in biomass. Sci Total Environ 301, 55-65, doi:10.1016/s00489697(02)00296-6 (2003).

136 Wolterbeek, H. T. \& Bode, P. Strategies in sampling and sample handling in the context of large-scale plant biomonitoring surveys of trace element air pollution. Sci Total Environ 176, 33-43, doi:10.1016/0048-9697(95)04828-6 (1995). 
137 Wolterbeek, H. T., Garty, J., Reis, M. A. \& Freitas, M. C. Biomonitors in use: lichens and metal air pollution. Bioindicators \& Biomonitors: Principles, Concepts and Applications 6, 377-419 (2003).

138 Nieboer, E. \& Richardson, D. H. S. Lichens as monitors of atmospheric deposition. Abstr Pap Am Chem S, 146-146 (1979).

139 Walther, D. A. et al. Temporal changes in metal levels of the lichens parmotrema-praesorediosum and ramalina-stenospora, southwest Louisiana. Water Air Soil Poll 53, 189-200 (1990).

140 Garty, J. Biomonitoring atmospheric heavy metals with lichens: Theory and application. Crit Rev Plant Sci 20, 309-371, doi:10.1016/s0735-2689(01)80040-x (2001).

141 Nickel, S. et al. Modelling and mapping heavy metal and nitrogen concentrations in moss in 2010 throughout Europe by applying Random Forests models. Atmos Environ 156, 146-159, doi:10.1016/j.atmosenv.2017.02.032 (2017).

142 Harmens, H. et al. Mosses as biomonitors of atmospheric heavy metal deposition: Spatial patterns and temporal trends in Europe. Environ Pollut 158, 3144-3156, doi:10.1016/j.envpol.2010.06.039 (2010).

143 St Pierre, K. A. et al. Importance of open marine waters to the enrichment of total mercury and monomethylmercury in lichens in the Canadian High Arctic. Environmental Science \& Technology 49, 5930-5938, doi:10.1021/acs.est.5b00347 (2015).

144 Agnan, Y., Le Dantec, T., Moore, C. W., Edwards, G. C. \& Obrist, D. New constraints on terrestrial surface atmosphere fluxes of gaseous elemental mercury using a global database. Environ Sci Technol 50, 507-524, doi:10.1021/acs.est.5b04013 (2016).

145 Frescholtz, T. F. \& Gustin, M. S. Soil and foliar mercury emission as a function of soil concentration. Water Air Soil Poll 155, 223-237, doi:10.1023/B:WATE.0000026530.85954.3f (2004).

146 Canario, J. et al. Salt-marsh plants as potential sources of $\mathrm{Hg}-0$ into the atmosphere. Atmos Environ 152, 458-464, doi:10.1016/j.atmosenv.2017.01.011 (2017).

147 Graydon, J. A., St Louis, V. L., Lindberg, S. E., Hintelmann, H. \& Krabbenhoft, D. P. Investigation of mercury exchange between forest canopy vegetation and the atmosphere using a new dynamic chamber. Environ Sci Technol 40, 4680-4688, doi:10.1021/es0604616 (2006).

148 Battke, F., Ernst, D. \& Halbach, S. Ascorbate promotes emission of mercury vapour from plants. Plant Cell and Environment 28, 1487-1495, doi:10.1111/j.1365-3040.2005.01385.x (2005).

149 Lindberg, S. E., Dong, W. J. \& Meyers, T. Transpiration of gaseous elemental mercury through vegetation in a subtropical wetland in Florida. Atmos Environ 36, 5207-5219, doi:10.1016/s13522310(02)00586-1 (2002).

150 Ericksen, J. A. et al. Accumulation of atmospheric mercury in forest foliage. Atmos Environ 37, 16131622, doi:10.1016/s1352-2310(03)00008-6 (2003).

151 Fay, L. \& Gustin, M. S. Investigation of mercury accumulation in cattails growing in constructed wetland mesocosms. Wetlands 27, 1056-1065, doi:10.1672/0277-5212(2007)27[1056:iomaic]2.0.co;2 (2007).

152 Sommar, J., Osterwalder, S. \& Zhu, W. Recent advances in understanding and measurement of Hg in the environment: Surface-atmosphere exchange of gaseous elemental mercury (Hg-0). Science of the Total Environment 721, doi:10.1016/j.scitotenv.2020.137648 (2020).

153 Hanson, P. J., Lindberg, S. E., Tabberer, T. A., Owens, J. G. \& Kim, K. H. Foliar Exchange of Mercury-Vapor - Evidence for a Compensation Point. Water Air Soil Poll 80, 373-382 (1995).

154 Stamenkovic, J. et al. Atmospheric mercury exchange with a tallgrass prairie ecosystem housed in mesocosms. Science of the Total Environment 406, 227-238, doi:10.1016/j.scitotenv.2008.07.047 (2008).

155 Zhou, J., Wang, Z., Zhang, X. \& Sun, T. Investigation of factors affecting mercury emission from subtropical forest soil: a field controlled study in southwestern China. Journal of Geochemical Exploration 176, 128-135 (2017).

156 Zhou, J., Wang, Z., Zhang, X., Driscoll, C. T. \& Lin, C. J. Soil-atmosphere exchange flux of total gaseous mercury (TGM) in subtropical and temperate forest catchments. Atmos. Chem. Phys. Discuss. 2020, 1-32, doi:10.5194/acp-2020-816 (2020). 
157 Bash, J. O. \& Miller, D. R. Growing season total gaseous mercury (TGM) flux measurements over an Acer rubrum L. stand. Atmos Environ 43, 5953-5961, doi:10.1016/j.atmosenv.2009.08.008 (2009).

158 Fritsche, J. et al. Summertime elemental mercury exchange of temperate grasslands on an ecosystemscale. Atmos Chem Phys 8, 7709-7722 (2008).

159 Lee, X., Benoit, G. \& Hu, X. Z. Total gaseous mercury concentration and flux over a coastal saltmarsh vegetation in Connecticut, USA. Atmos Environ 34, 4205-4213, doi:10.1016/s1352-2310(99)00487-2 (2000).

160 Slemr, F. et al. in Proceedings of the 16th International Conference on Heavy Metals in the Environment Vol. 1 E3S Web of Conferences (ed N. Pirrone) (2013).

161 Yuan, W. et al. Process factors driving dynamic exchange of elemental mercury vapor over soil in broadleaf forest ecosystems. Atmos Environ 219, 117047, doi:10.1016/j.atmosenv.2019.117047 (2019).

162 Castro, M. S. \& Moore, C. W. Importance of gaseous elemental mercury fluxes in western Maryland. Atmosphere 7, 110 (2016).

163 Obrist, D. et al. Direct measurement of gaseous mercury deposition in a temperate deciduous forest in review (2020).

164 Castro, M., S. \& Moore, C., W. . Importance of Gaseous Elemental Mercury Fluxes in Western Maryland. Atmosphere, Vol 7, Iss 9, p 110 (2016), 110, doi:10.3390/atmos7090110 (2016).

165 Osterwalder, S. et al. Mercury evasion from a boreal peatland shortens the timeline for recovery from legacy pollution. Sci Rep 7, doi:10.1038/s41598-017-16141-7 (2017).

$166 \mathrm{Yu}$, Q. et al. Gaseous elemental mercury (GEM) fluxes over canopy of two typical subtropical forests in south China. Atmospheric Chemistry and Physics 18, 495-509, doi:10.5194/acp-18-495-2018 (2018).

167 Baya, A. P. \& Van Heyst, B. Assessing the trends and effects of environmental parameters on the behaviour of mercury in the lower atmosphere over cropped land over four seasons. Atmos Chem Phys 10, 8617-8628, doi:10.5194/acp-10-8617-2010 (2010).

168 Zhu, W., Sommar, J., Lin, C. J. \& Feng, X. Mercury vapor air-surface exchange measured by collocated micrometeorological and enclosure methods - Part II: Bias and uncertainty analysis. Atmos Chem Phys 15, 5359-5376, doi:10.5194/acp-15-5359-2015 (2015).

169 Blum, J. D., Sherman, L. S. \& Johnson, M. W. Mercury isotopes in earth and environmental sciences. Annual Review of Earth and Planetary Sciences 42, 249-269, doi:10.1146/annurev-earth-050212124107 (2014).

170 Kwon, S. Y. et al. Mercury stable isotopes for monitoring the effectiveness of the Minamata Convention on Mercury. Earth-Science Reviews, doi:https://doi.org/10.1016/j.earscirev.2020.103111 (2020).

171 Gratz, L. E., Keeler, G. J., Blum, J. D. \& Sherman, L. S. Isotopic composition and fractionation of mercury in great lakes precipitation and ambient air. Environmental Science \& Technology 44, 77647770, doi:10.1021/es100383w (2010).

172 Chen, J., Hintelmann, H., Feng, X. \& Dimock, B. Unusual fractionation of both odd and even mercury isotopes in precipitation from Peterborough, ON, Canada. Geochimica et Cosmochimica Acta 90, 3346, doi:10.1016/j.gca.2012.05.005 (2012).

173 Sherman, L. S., Blum, J. D., Keeler, G. J., Demers, J. D. \& Dvonch, J. T. Investigation of local mercury deposition from a coal-fired power plant using mercury isotopes. Environmental Science \& Technology 46, 382-390, doi:10.1021/es202793c (2012).

174 Demers, J. D., Blum, J. D. \& Zak, D. R. Mercury isotopes in a forested ecosystem: Implications for air-surface exchange dynamics and the global mercury cycle. Global Biogeochemical Cycles 27, 222238, doi:Doi 10.1002/Gbc.20021 (2013).

175 Demers, J. D., Sherman, L. S., Blum, J. D., Marsik, F. J. \& Dvonch, J. T. Coupling atmospheric mercury isotope ratios and meteorology to identify sources of mercury impacting a coastal urbanindustrial region near Pensacola, Florida, USA. Global Biogeochemical Cycles 29, 1689-1705, doi:10.1002/2015gb005146 (2015). 
176 Wang, Z. et al. Mass-dependent and mass-independent fractionation of mercury isotopes in precipitation from Guiyang, SW China. Comptes Rendus Geoscience 347, 358-367, doi:http://dx.doi.org/10.1016/j.crte.2015.02.006 (2015).

$177 \mathrm{Fu}$, X., Marusczak, N., Wang, X., Gheusi, F. \& Sonke, J. E. Isotopic composition of gaseous elemental mercury in the free troposphere of the Pic du Midi Observatory, France. Environ Sci Technol 50, 56415650, doi:10.1021/acs.est.6b00033 (2016).

$178 \mathrm{Yu}, \mathrm{B}$. et al. Isotopic composition of atmospheric mercury in china: New evidence for sources and transformation processes in air and in vegetation. Environ Sci Technol 50, 9262-9269, doi:10.1021/acs.est.6b01782 (2016).

179 Tsui, M. T. et al. Sources and transfers of methylmercury in adjacent river and forest food webs. Environmental Science \& Technology 46, 10957-10964, doi:10.1021/es3019836 (2012).

$180 \mathrm{Liu}, \mathrm{H} .-\mathrm{w}$. et al. Mercury isotopic compositions of mosses, conifer needles, and surface soils: Implications for mercury distribution and sources in Shergyla Mountain, Tibetan Plateau. Ecotox Environ Safe 172, 225-231, doi:https://doi.org/10.1016/j.ecoenv.2019.01.082 (2019).

181 Jiskra, M. et al. Mercury deposition and re-emission pathways in boreal forest soils investigated with $\mathrm{Hg}$ isotope signatures. Environmental Science \& Technology 49, 7188-7196, doi:10.1021/acs.est.5b00742 (2015).

182 Zheng, W., Obrist, D., Weis, D. \& Bergquist, B. A. Mercury isotope compositions across North American forests. Global Biogeochem Cy 30, 1475-1492, doi:doi:10.1002/2015GB005323 (2016).

183 Woerndle, G. E. et al. New insights on ecosystem mercury cycling revealed by stable isotopes of mercury in water flowing from a headwater peatland catchment. Environ Sci Technol 52, 1854-1861, doi:10.1021/acs.est.7b04449 (2018).

$184 \mathrm{Fu}, \mathrm{X}$. et al. Significant seasonal variations in isotopic composition of atmospheric total gaseous mercury at forest sites in china caused by vegetation and mercury sources. Environmental Science \& Technology 53, 13748-13756 (2019).

185 Sun, R. et al. Modelling the mercury stable isotope distribution of Earth surface reservoirs: implications for global $\mathrm{Hg}$ cycling. Geochimica et Cosmochimica Acta 246, 156-173 (2019).

186 Wang, X. et al. Climate and vegetation as primary drivers for global mercury storage in surface soil. Environmental Science \& Technology 53, 10665-10675, doi:10.1021/acs.est.9b02386 (2019).

187 Biswas, A., Blum, J. D., Bergquist, B. A., Keeler, G. J. \& Xie, Z. Q. Natural Mercury Isotope Variation in Coal Deposits and Organic Soils. Environ Sci Technol 42, 8303-8309, doi:10.1021/es801444b (2008).

188 Guedron, S. et al. Mercury isotopic fractionation during pedogenesis in a tropical forest soil catena (French Guiana): Deciphering the impact of historical gold mining. Environ Sci Technol 52, 1157311582, doi:10.1021/acs.est.8b02186 (2018).

189 Jiskra, M., Wiederhold, J. G., Skyllberg, U., Kronberg, R. M. \& Kretzschmar, R. Source tracing of natural organic matter bound mercury in boreal forest runoff with mercury stable isotopes. Environmental Science: Processes \& Impacts 19, 1235-1248, doi:10.1039/c7em00245a (2017).

190 Grasby, S. E. et al. Isotopic signatures of mercury contamination in latest Permian oceans. Geology 45, 55-58, doi:10.1130/g38487.1 (2017).

191 Lepak, R. F. et al. Use of stable isotope signatures to determine mercury sources in the Great Lakes. Environmental Science \& Technology Letters 2, 335-341, doi:10.1021/acs.estlett.5b00277 (2015).

192 Araujo, B. F., Hintelmann, H., Dimock, B., Almeida, M. G. \& Rezende, C. E. Concentrations and isotope ratios of mercury in sediments from shelf and continental slope at Campos Basin near Rio de Janeiro, Brazil. Chemosphere 178, 42-50, doi:10.1016/j.chemosphere.2017.03.056 (2017).

193 Gleason, J. D. et al. Sources and cycling of mercury in the paleo Arctic Ocean from $\mathrm{Hg}$ stable isotope variations in Eocene and Quaternary sediments. Geochim Cosmochim Ac 197, 245-262, doi:10.1016/j.gca.2016.10.033 (2017).

194 Masbou, J. et al. Hg-stable isotope variations in marine top predators of the Western Arctic Ocean. ACS Earth and Space Chemistry 2, 479-490, doi:10.1021/acsearthspacechem.8b00017 (2018). 
$195 \mathrm{Fu}$, X. et al. Atmospheric wet and litterfall mercury deposition at urban and rural sites in China. Atmos Chem Phys 16, 11547-11562, doi:10.5194/acp-16-11547-2016 (2016).

196 Wright, L. P., Zhang, L. \& Marsik, F. J. Overview of mercury dry deposition, litterfall, and throughfall studies. Atmospheric Chemistry and Physics 16, 13399-13416, doi:10.5194/acp-16-13399-2016 (2016).

197 Zhang, L. et al. The estimated six-year mercury dry deposition across North America. Environmental Science \& Technology 50, 12864-12873, doi:10.1021/acs.est.6b04276 (2016).

198 Wang, X., Bao, Z. D., Lin, C. J., Yuan, W. \& Feng, X. B. Assessment of global mercury deposition through litterfall. Environ Sci Technol 50, 8548-8557, doi:10.1021/acs.est.5b06351 (2016).

199 Cooke, C. A., Martinez-Cortizas, A., Bindler, R. \& Gustin, M. S. Environmental archives of atmospheric $\mathrm{Hg}$ deposition - A review. Sci Total Environ 709, 134800, doi:10.1016/j.scitotenv.2019.134800 (2020).

200 Zhang, H., Holmes, C. D. \& Wu, S. Impacts of of changes in climate, land use and land cover on atmospheric mercury. Atmos Environ 141, 230-244, doi:10.1016/j.atmosenv.2016.06.056 (2016).

201 Melendez-Perez, J. J. et al. Soil and biomass mercury emissions during a prescribed fire in the Amazonian rain forest. Atmos Environ 96, 415-422, doi:10.1016/j.atmosenv.2014.06.032 (2014).

202 Richardson, J. B. \& Friedland, A. J. Mercury in coniferous and deciduous upland forests in northern New England, USA: implications of climate change. Biogeosciences 12, 6737-6749, doi:10.5194/bgd12-11463-2015 (2015).

203 Yang, Y., Yanai, R. D., Driscoll, C. T., Montesdeoca, M. \& Smith, K. T. Concentrations and content of mercury in bark, wood, and leaves in hardwoods and conifers in four forested sites in the northeastern USA. Plos One 13, e0196293, doi:10.1371/journal.pone.0196293 (2018).

204 Zhou, J., Wang, Z. W., Zhang, X. S. \& Gao, Y. Mercury concentrations and pools in four adjacent coniferous and deciduous upland forests in Beijing, China. J Geophys Res-Biogeo 122, 1260-1274, doi:10.1002/2017jg003776 (2017).

205 Obrist, D. Atmospheric mercury pollution due to losses of terrestrial carbon pools? Biogeochemistry 85, 119-123, doi:10.1007/s10533-007-9108-0 (2007).

206 Demers, J. D., Driscoll, C. T., Fahey, T. J. \& Yavitt, J. B. Mercury cycling in litter and soil in different forest types in the Adirondack region, New York, USA. Ecol Appl 17, 1341-1351 (2007).

207 Heyes, A., Moore, T. R. \& Rudd, J. W. M. Mercury and methylmercury in decomposing vegetation of a pristine and impounded wetland. Journal of Environmental Quality 27, 591-599, doi:10.2134/jeq1998.00472425002700030017x (1998).

208 Wang, X. et al. Enhanced accumulation and storage of mercury on subtropical evergreen forest floor: Implications on mercury budget in global forest ecosystems. Journal of Geophysical ResearchBiogeosciences 121, 2096-2109, doi:10.1002/2016jg003446 (2016).

209 Zhou, J., Wang, Z. W. \& Zhang, X. S. Deposition and fate of mercury in litterfall, litter, and soil in coniferous and broad-leaved forests. Journal of Geophysical Research-Biogeosciences 123, 25902603, doi:10.1029/2018jg004415 (2018).

210 Yuan, W. et al. Stable Mercury Isotope Transition during Postdepositional Decomposition of Biomass in a Forest Ecosystem over Five Centuries. Environ Sci Technol 54, 8739-8749, doi:10.1021/acs.est.0c00950 (2020).

211 Pokharel, A. K. \& Obrist, D. Fate of mercury in tree litter during decomposition. Biogeosciences 8, 2507-2521, doi:10.5194/bg-8-2507-2011 (2011).

$212 \mathrm{Lim}, \mathrm{A}$. G. et al. A revised pan-Arctic permafrost soil $\mathrm{Hg}$ pool based on Western Siberian peat $\mathrm{Hg}$ and carbon observations. Biogeosciences 17, 3083-3097 (2020).

213 Wright, L. P. \& Zhang, L. An approach estimating bidirectional air-surface exchange for gaseous elemental mercury at AMNet sites. Journal of Advances in Modeling Earth Systems 7, 35-49, doi:10.1002/2014ms000367 (2015).

$214 \mathrm{Zhu}, \mathrm{W}$. et al. Global observations and modeling of atmosphere-surface exchange of elemental mercury: a critical review. Atmos Chem Phys 16, 4451-4480 (2016). 
215 Wesely, M. L. \& Hicks, B. B. A review of the current status of knowledge on dry deposition. Atmospheric Environment 34, 2261-2282, doi:10.1016/s1352-2310(99)00467-7 (2000).

216 Christensen, J. H., Brandt, J., Frohn, L. M. \& Skov, H. Modelling of mercury in the Arctic with the Danish Eulerian Hemispheric Model. Atmospheric Chemistry and Physics 4, 2251-2257, doi:10.5194/acp-4-2251-2004 (2004).

217 De Simone, F., Gencarelli, C. N., Hedgecock, I. M. \& Pirrone, N. Global atmospheric cycle of mercury: a model study on the impact of oxidation mechanisms. Environmental Science and Pollution Research 21, 4110-4123, doi:10.1007/s11356-013-2451-x (2014).

218 Holmes, C. D., Jacob, D. J., Soerensen, A. L. \& Corbitt, E. S. Global atmospheric budget of mercury including oxidation of $\mathrm{Hg}(0)$ by bromine atoms. Geochimica Et Cosmochimica Acta 74, A413-A413 (2010).

219 Travnikov, O. \& Ilyin, I. in Mercury Fate and Transport in the Global Atmosphere 571-587 (Springer, 2009).

220 Kerkweg, A. et al. An implementation of the dry removal processes DRY DEPosition and SEDImentation in the Modular Earth Submodel System (MESSy). (2006).

221 Wesely, M. L. \& Lesht, B. M. Comparison of RADM dry deposition algorithms with a site-specific method for inferring dry deposition. Water Air and Soil Pollution 44, 273-293, doi:10.1007/bf00279259 (1989).

222 Zhang, L., Brook, J. \& Vet, R. A revised parameterization for gaseous dry deposition in air-quality models. Atmospheric Chemistry and Physics 3, 2067-2082 (2003).

223 Zhang, L., Wright, L. P. \& Blanchard, P. A review of current knowledge concerning dry deposition of atmospheric mercury. Atmospheric Environment 43, 5853-5864 (2009).

224 Huang, J., Miller, M. B., Edgerton, E. \& Gustin, M. S. Deciphering potential chemical compounds of gaseous oxidized mercury in Florida, USA. Atmospheric Chemistry and Physics 17, 1689-1698, doi:10.5194/acp-17-1689-2017 (2017).

225 Travnikov, O. et al. Multi-model study of mercury dispersion in the atmosphere: atmospheric processes and model evaluation. Atmospheric Chemistry and Physics 17, 5271-5295, doi:10.5194/acp17-5271-2017 (2017).

226 Bash, J. O., Miller, D. R., Meyer, T. H. \& Bresnahan, P. A. Northeast United States and Southeast Canada natural mercury emissions estimated with a surface emission model. Atmospheric Environment 38, 5683-5692, doi:10.1016/j.atmosenv.2004.05.058 (2004).

227 Durnford, D. et al. How relevant is the deposition of mercury onto snowpacks? - Part 2: A modeling study. Atmospheric Chemistry and Physics 12, 9251-9274, doi:10.5194/acp-12-9251-2012 (2012).

228 Fisher, L. S. \& Wolfe, M. H. Examination of mercury inputs by throughfall and litterfall in the Great Smoky Mountains National Park. Atmospheric Environment 47, 554-559, doi:10.1016/j.atmosenv.2011.10.017 (2012).

229 Gbor, P. K. et al. Improved model for mercury emission, transport and deposition. Atmospheric Environment 40, 973-983, doi:10.1016/j.atmosenv.2005.10.040 (2006).

230 Lin, C. J., Lindberg, S. E., Ho, T. C. \& Jang, C. Development of a processor in BEIS3 for estimating vegetative mercury emission in the continental United States. Atmospheric Environment 39, 75297540, doi:10.1016/j.atmosenv.2005.04.044 (2005).

231 Selin, N. E. et al. Global 3-D land-ocean-atmosphere model for mercury: Present-day versus preindustrial cycles and anthropogenic enrichment factors for deposition. Global Biogeochemical Cycles 22, doi:10.1029/2007gb003040 (2008).

232 Shetty, S. K., Lin, C.-J., Streets, D. G. \& Jang, C. Model estimate of mercury emission from natural sources in East Asia. Atmospheric Environment 42, 8674-8685, doi:10.1016/j.atmosenv.2008.08.026 (2008).

233 Smith-Downey, N. V., Sunderland, E. M. \& Jacob, D. J. Anthropogenic impacts on global storage and emissions of mercury from terrestrial soils: Insights from a new global model. Journal of Geophysical Research-Biogeosciences 115, doi:10.1029/2009jg001124 (2010). 
234 Xu, X. H., Yang, X. S., Miller, D. R., Helble, J. J. \& Carley, R. J. Formulation of bi-directional atmosphere-surface exchanges of elemental mercury. Atmospheric Environment 33, 4345-4355, doi:10.1016/s1352-2310(99)00245-9 (1999).

235 Bash, J. O. Description and initial simulation of a dynamic bidirectional air-surface exchange model for mercury in Community Multiscale Air Quality (CMAQ) model. Journal of Geophysical ResearchAtmospheres 115, doi:10.1029/2009jd012834 (2010).

236 Wang, X., Lin, C. J. \& Feng, X. Sensitivity analysis of an updated bidirectional air-surface exchange model for elemental mercury vapor. Atmospheric Chemistry and Physics 14, 6273-6287, doi:10.5194/acp-14-6273-2014 (2014).

237 Lin, C.-J. et al. Scientific uncertainties in atmospheric mercury models I: Model science evaluation. Atmos Environ 40, 2911-2928, doi:10.1016/j.atmosenv.2006.01.009 (2006).

238 Graydon, J. A. et al. Investigation of uptake and retention of atmospheric $\mathrm{Hg}$ (II) by boreal forest plants using stable Hg isotopes. Environmental science \& technology 43, 4960-4966 (2009).

239 Zhang, H. et al. Assessing air-surface exchange and fate of mercury in a subtropical forest using a novel passive exchange-meter device. Environmental Science \& Technology 53, 4869-4879, doi:10.1021/acs.est.8b06343 (2019).

240 Khan, T. R., Obrist, D., Agnan, Y., Selin, N. E. \& Perlinger, J. A. Atmosphere-terrestrial exchange of gaseous elemental mercury: parameterization improvement through direct comparison with measured ecosystem fluxes. Environmental Science-Processes \& Impacts 21, 1699-1712, doi:10.1039/c9em00341j (2019).

241 Dastoor, A. P. \& Larocque, Y. Global circulation of atmospheric mercury: a modelling study. Atmos Environ 38, 147-161, doi:10.1016/j.atmosenv.2003.08.037 (2004).

242 Fraser, A., Dastoor, A. \& Ryjkov, A. How important is biomass burning in Canada to mercury contamination? Atmospheric Chemistry and Physics 18, 7263-7286, doi:10.5194/acp-18-7263-2018 (2018).

243 Angot, H. et al. Global and local impacts of delayed mercury mitigation efforts. Environmental Science \& Technology 52, 12968-12977, doi:10.1021/acs.est.8b04542 (2018).

244 Kwon, S. Y. \& Selin, N. E. Uncertainties in atmospheric mercury modeling for policy evaluation. Current Pollution Reports 2, 103-114, doi:10.1007/s40726-016-0030-8 (2016).

$245 \mathrm{Liu}, \mathrm{Z}$. et al. A review on phytoremediation of mercury contaminated soils. Journal of hazardous materials, 123138 (2020).

246 Anjum, N. A., Duarte, A. C., Pereira, E. \& Ahmad, I. Juncus maritimus root biochemical assessment for its mercury stabilization potential in Ria de Aveiro coastal lagoon (Portugal). Environ Sci Pollut $R$ 22, 2231-2238, doi:10.1007/s11356-014-3455-x (2015).

247 Shehu, J. et al. Hyperaccumulators of mercury in the industrial area of a pvc factory in Vlora (Albania). Archives of Biological Sciences 66, 1457-1463, doi:10.2298/abs1404457s (2014).

248 Qian, X. et al. Total mercury and methylmercury accumulation in wild plants grown at wastelands composed of mine tailings: Insights into potential candidates for phytoremediation. Environ Pollut 239, 757-767, doi:10.1016/j.envpol.2018.04.105 (2018).

249 Pogrzeba, M. et al. Dactylis glomerata L. cultivation on mercury contaminated soil and its physiological response to granular sulphur aided phytostabilization. Environ Pollut 255, doi:10.1016/j.envpol.2019.113271 (2019).

250 Moreno, F. N. et al. Effect of thioligands on plant-Hg accumulation and volatilisation from mercurycontaminated mine tailings. Plant and Soil 275, 233-246, doi:10.1007/s11104-005-1755-0 (2005).

251 Rascio, N. \& Navari-Izzo, F. Heavy metal hyperaccumulating plants: How and why do they do it? And what makes them so interesting? Plant Science 180, 169-181, doi:10.1016/j.plantsci.2010.08.016 (2011).

252 Wang, J. et al. Ammonium thiosulphate enhanced phytoextraction from mercury contaminated soil Results from a greenhouse study. J Hazard Mater 186, 119-127, doi:10.1016/j.jhazmat.2010.10.097 (2011). 
253 Franchi, E. et al. Phytoremediation of a multi contaminated soil: mercury and arsenic phytoextraction assisted by mobilizing agent and plant growth promoting bacteria. J Soil Sediment 17, 1224-1236, doi:10.1007/s11368-015-1346-5 (2017).

254 Smolinska, B. The influence of compost and nitrilotriacetic acid on mercury phytoextraction by Lepidium sativum L. Journal of Chemical Technology and Biotechnology 95, 950-958, doi:10.1002/jctb.5970 (2020).

255 Wang, J. et al. Thiosulphate-induced phytoextraction of mercury in Brassica juncea: Spectroscopic investigations to define a mechanism for $\mathrm{Hg}$ uptake. Environ Pollut 242, 986-993, doi:10.1016/j.envpol.2018.07.065 (2018).

256 Fan, Y. et al. Phytoextraction potential of soils highly polluted with cadmium using the cadmium/zinc hyperaccumulator Sedum plumbizincicola. International Journal of Phytoremediation 21, 733-741, doi:10.1080/15226514.2018.1556592 (2019).

257 Cole, A. et al. Ten-year trends of atmospheric mercury in the high Arctic compared to Canadian subArctic and mid-latitude sites. Atmospheric Chemistry and Physics 13, 1535-1545 (2013).

258 Gay, D. A. et al. The Atmospheric Mercury Network: measurement and initial examination of an ongoing atmospheric mercury record across North America. Atmos. Chem. Phys 13, 11339-11349 (2013).

259 Tørseth, K. et al. Introduction to the European Monitoring and Evaluation Programme (EMEP) and observed atmospheric composition change during 1972-2009. Atmospheric Chemistry and Physics 12, 5447-5481 (2012).

260 Sprovieri, F. et al. Atmospheric mercury concentrations observed at ground-based monitoring sites globally distributed in the framework of the GMOS network. Atmos Chem Phys 16, 11915-11935, doi:10.5194/acp-16-11915-2016 (2016).

261 Custodio, D., Ebinghaus, R., Spain, T. G. \& Bieser, J. Source apportionment of atmospheric mercury in the remote marine atmosphere: Mace Head GAW station, Irish western coast. Atmospheric Chemistry and Physics 20, $7929-7939$ (2020).

262 Slemr, F. et al. Atmospheric mercury in the Southern Hemisphere-Part 1: Trend and inter-annual variations in atmospheric mercury at Cape Point, South Africa, in 2007-2017, and on Amsterdam Island in 2012-2017. Atmospheric Chemistry and Physics 20, 7683-7692 (2020).

263 Slemr, F. et al. Comparison of mercury concentrations measured at several sites in the Southern Hemisphere. Atmospheric Chemistry and Physics 15, 3125-3133 (2015).

264 Howard, D. et al. Atmospheric mercury in the Southern Hemisphere tropics: seasonal and diurnal variations and influence of inter-hemispheric transport. (2017).

265 McLagan, D. S. et al. Global evaluation and calibration of a passive air sampler for gaseous mercury. Atmospheric Chemistry and Physics 18, 5905-5919 (2018). 


\section{References recommendation:}

1. Outridge, P.M., Mason, R.P., Wang, F., Guerrero, S. \& Heimburger-Boavida, L.E. Updated global and oceanic mercury budgets for the united nations global mercury assessment 2018. Environmental Science \& Technology 52, 11466-11477 (2018).

This paper presents current understanding of the global environmental mercury cycling by reporting estimates and uncertainties of global mercury emissions, fluxes and budgets.

2. Jiskra, M. et al. A vegetation control on seasonal variations in global atmospheric mercury concentrations. Nature Geoscience 11, 244-250 (2018).

Terrestrial vegetation acts as a global $\mathrm{Hg}(0)$ pump, which controls seasonal variations of atmospheric $\operatorname{Hg}(\mathbf{0})$

3. Travnikov, O. et al. Multi-model study of mercury dispersion in the atmosphere: atmospheric processes and model evaluation. Atmospheric Chemistry and Physics 17, 5271-5295 (2017).

This study provides a review of the global $\mathrm{Hg}$ models in literature, and their differences, uncertainties and evaluation with measurements.

4. Khan, T.R., Obrist, D., Agnan, Y., Selin, N.E. \& Perlinger, J.A. Atmosphere-terrestrial exchange of gaseous elemental mercury: parameterization improvement through direct comparison with measured ecosystem fluxes. Environmental Science-Processes \& Impacts 21, 1699-1712 (2019).

The use of resistance-based models combined with the new soil reemission flux parameterization is able to reproduce observed diel and seasonal patterns of $\mathrm{HgO}$ exchange in these ecosystems.

5. Zhang, L. et al. The estimated six-year mercury dry deposition across North America. Environmental Science \& Technology 50, 12864-12873 (2016).

GEM dry deposition over vegetated surfaces will not decrease, and sometimes may even increase with decreasing anthropogenic emissions 
6. Bishop, K.H., Lee, Y.H., Munthe, J. \& Dambrine, E. Xylem sap as a pathway for total mercury and methylmercury transport from soils to tree canopy in the boreal forest. Biogeochemistry 40, 101-113 (1998).

$11 \%$ of the THg in litterfall was transported from soils to needles in xylem sap.

7. Bargagli, R. Moss and lichen biomonitoring of atmospheric mercury: A review. Science of the Total Environment 572, 216-231 (2016).

Cryptogams are good biomonitors of $\mathrm{Hg}$ natural/anthropogenic point sources, but estimates of air Hg concentrations and fluxes based on cryptogams are not reliable.

8. Manceau, A., Wang, J., Rovezzi, M., Glatzel, P. \& Feng, X. Biogenesis of mercury-sulfur nanoparticles in plant leaves from atmospheric gaseous mercury. Environmental science \& technology 52, 3935-3948 (2018).

Spectroscopic study reported the formation of stable Hg sulfur nanoparticles in foliage.

9. Arnold, J., Gustin, M.S. \& Weisberg, P.J. Evidence for nonstomatal uptake of $\mathrm{Hg}$ by aspen and translocation of $\mathrm{Hg}$ from foliage to tree rings in Austrian pine. Environmental Science \& Technology 52, 1174-1182 (2018).

Hg accumulation into tree rings is by way of the stomata and subsequent translocation by way of phloem, and the use of trees as temporal proxies requires further investigation.

10. Wang, X. et al. Global warming accelerates uptake of atmospheric mercury in regions experiencing glacier retreat. Proceedings of the National Academy of Sciences of the United States of America 117, 2049-2055 (2020).

400 to $600 \mathrm{Mg}$ of $\mathrm{Hg}$ has been accumulated in glacier-retreated area since the 1850 , and additional $\sim 300 \mathrm{Mg}$ of $\mathrm{Hg}$ will be sequestered from the atmosphere in glacier-retreated regions globally, which is $\sim 3$ times the total $\mathrm{Hg}$ mass loss by meltwater efflux ( $\sim 95 \mathrm{Mg})$ in alpine and subpolar glacier regions.

11. Obrist, D. et al. A review of global environmental mercury processes in response to human and natural perturbations: Changes of emissions, climate, and land use. Ambio 47, 116-140 (2018). 
The paper reviewed the $\mathrm{Hg}$ wet and dry deposition to terrestrial ecosystem, ocean $\mathrm{Hg}(0)$ evasion to the atmosphere, and global aquatic $\mathrm{Hg}$ releases and predict that land use and climate change impacts on $\mathrm{Hg}$ cycling will be large and inherently linked to changes in ecosystem function and global atmospheric and ocean circulations.

12. Wang, J.J. et al. Fine Root Mercury Heterogeneity: Metabolism of Lower-Order Roots as an Effective Route for Mercury Removal. Environmental Science \& Technology 46, 769-777 (2012).

The estimated Hg return flux from dead fine roots outweighed that from leaf litter, and ephemeral first-order roots that constituted $7.2-22.3 \%$ of total fine root biomass may have contributed most to this flux.

13. Agnan, Y., Le Dantec, T., Moore, C.W., Edwards, G.C. \& Obrist, D. New Constraints on Terrestrial Surface Atmosphere Fluxes of Gaseous Elemental Mercury Using a Global Database. Environmental Science \& Technology 50, 507-524 (2016).

Using available terrestrial surface-atmosphere $\operatorname{Hg}(0)$ flux studies reveals that based on the current measurements available, global assimilation by vegetation cannot be determined appropriately with global flux uncertainty ranging from a net deposition of $513 \mathrm{Mg}$ to a net emission of $1353 \mathrm{Mg}^{-1}$.

14. Wang, X., Bao, Z., Lin, C.-J., Yuan, W. \& Feng, X. Assessment of global mercury deposition through litterfall. Environmental Science \& Technology 50, 8548-8557 (2016).

This is the first study that estimated the global spatial distribution and budget of Hg dry deposition via plant Hg uptake using comprehensive litterfall data.

15. Yuan, W. et al. Stable Isotope Evidence Shows Re-emission of Elemental Mercury Vapor Occurring after Reductive Loss from Foliage. Environmental Science \& Technology 53, 651-660 (2019).

Leaf-level study showed odd-MIF isotope fractionation during photochemical reduction and reemission from foliage.

16. Demers, J.D., Blum, J.D. \& Zak, D.R. Mercury isotopes in a forested ecosystem: Implications for airsurface exchange dynamics and the global mercury cycle. Global Biogeochemical Cycles 27, 222-238 (2013). 
Forest ecosystem study using Hg stable isotopes showed that dry deposition represents major deposition pathway

17. Enrico, M. et al. Atmospheric mercury transfer to peat bogs dominated by gaseous elemental mercury dry deposition. Environmental Science \& Technology 50, 2405-12 (2016).

Study proposed $\Delta^{200} \mathrm{Hg}$ as conservative tracer for atmospheric deposition pathways.

18. Zhu, W. et al. Global observations and modeling of atmosphere-surface exchange of elemental mercury: a critical review. Atmospheric Chemistry and Physics 16, 4451-4480 (2016).

This study is a critical review of the state of science in the atmosphere-surface exchange mechanisms, observation techniques, and model parameterizations.

19. Bash, J.O. Description and initial simulation of a dynamic bidirectional air-surface exchange model for mercury in Community Multiscale Air Quality (CMAQ) model. Journal of Geophysical ResearchAtmospheres 115 (2010).

This paper describes the most comprehensive scheme for modeling bidirectional Hg exchange fluxes over vegetation canopy by defining dynamic compensation points based on partitioning coefficients across air-foliage and -soil surfaces.

20. Obrist, D. et al. Tundra uptake of atmospheric elemental mercury drives Arctic mercury pollution. Nature 547, 201-204, 2017.

This paper conducted two years of measurements of mercury deposition, including gaseous $\mathrm{Hg}(\mathbf{0})$ deposition by means of a micrometeorological method. The study found that $71 \%$ of total deposition was derived from gaseous dry deposition of $\operatorname{Hg}(0)$, a finding which was consistent with source characterization in plants and soils using stable $\mathrm{Hg}$ isotopes. 


\section{Glossary terms:}

Add glossary term for Minamata Convention: An international treaty named after the city of Minamata in Japan that experienced devastating $\mathrm{Hg}$ contamination in the 1950 s.

Add glossary term for vascular plants: Group of plants with specialized tissues that include coniferous and flowering plants.

Add glossary term for stomata: Stomata are apertures in leaves that control gas exchange (e.g., carbon dioxide and water vapor) between plants and the atmosphere.

Add glossary term for cuticle: Outer, protective layer on epidermal cells of leaves, often consisting of waxy, water-repellent substances.

Add glossary term for Physiology: The study of plant function and behavior, including growth, metabolism, reproduction, defence, and communication.

Add Glossary Term for non-vascular plants: plants that do not have specialized vascular tissues, which include algae, mosses, livermorts and horworts. Often, lichen are grouped into this category, although they are symbiotic partnerships between a fungus and an algae. 